\title{
Influence of mussel aquaculture on nitrogen dynamics in a nutrient enriched coastal embayment
}

\author{
Peter J. Cranford ${ }^{1, *}$, Peter M. Strain ${ }^{1}$, Michael Dowd ${ }^{2}$, Barry T. Hargrave ${ }^{1}$, \\ Jonathan Grant ${ }^{3}$, Marie-Claude Archambault ${ }^{3}$ \\ ${ }^{1}$ Ecosystem Research Division, Fisheries and Oceans Canada, Bedford Institute of Oceanography, PO Box 1006, \\ Dartmouth, Nova Scotia B2Y 4A2, Canada \\ ${ }^{2}$ Department of Mathematics and Statistics, Dalhousie University, Halifax, Nova Scotia B3H 3J5, Canada \\ ${ }^{3}$ Department of Oceanography, Dalhousie University, Halifax, Nova Scotia B3H 4J1, Canada
}

\begin{abstract}
The combined influences of intensive mussel aquaculture and watershed nutrient inputs on nitrogen dynamics in Tracadie Bay, Prince Edward Island, Canada, were examined using a nitrogen budget and an ecosystem model. Budget calculations, and inputs and parameters for the model were based on extensive field data. Both approaches showed that mussel aquaculture has a dominant influence on all aspects of the nitrogen cycle and dramatically alters pathways by which nitrogen reaches the phytoplankton and benthos. A large proportion of phytoplankton production is supported by land-derived nitrogen and this anthropogenic input is important for sustaining existing levels of mussel production. The amount of nitrogen removed in the mussel harvest is small compared with agricultural nitrogen inputs and the amounts excreted and biodeposited on the seabed. Mussel biodeposition greatly increases the flux of nitrogen to the benthos, with potentially serious eutrophication impacts. Results from the observation-based nitrogen budget and dynamic model were compared and both support the above conclusions. However, the ability of the model to test different scenarios and to provide additional information (e.g. fluxes) over a finer spatial scale led to insights unattainable with a nitrogen budget. For example, food appears to be less available to mussels at the head of the Bay than at the mouth, despite the lower density of grow-out sites in the former location. The number of fundamental ecosystem processes influenced by the mussels and the complexity of their interactions make it difficult to predict the effects of mussels on many ecosystem properties without resorting to a model.
\end{abstract}

KEY WORDS: Eutrophication • Nitrogen cycling • Nitrogen budget • Ecosystem model . Ecophysiology $\cdot$ Biodeposition $\cdot$ Excretion

\section{INTRODUCTION}

Natural and farmed populations of suspension feeding bivalve molluscs exert a dominant influence on energy flow and nutrient cycling in many coastal marine ecosystems, particularly in inlets where water residence time is long and bivalve biomass is high (Smaal \& Prins 1993, Dame 1996, Dame \& Prins 1998, Cranford et al. 2003, Newell 2004, Grant et al. 2005). By creating structurally complex shell habitats and performing a wide array of ecological functions, bi- valve populations can substantially modify benthic and pelagic communities at different trophic levels and alter energy flow and nutrient cycling over the scale of entire coastal ecosystems. Potential mechanisms for ecosystem effects include the utilization of particulate food resources by the bivalves, the biodeposition of faeces and pseudofaeces, and the excretion of metabolites. Bivalve aquaculture is expanding rapidly in many countries and a comprehensive understanding of the influence of this industry on coastal ecosystems, as well as interactions with other anthropogenic stressors, 
is fundamental for developing strategies for the sustainable management of the coastal zone as well as the aquaculture industry.

Dense bivalve populations and communities are known to influence the nitrogen cycle in coastal ecosystems, with the degree of control depending largely on site-specific hydrographic conditions (Dame 1996, Newell 2004). Bivalves exert 'bottom-up' nutrient control on the phytoplankton by (1) the excretion of large amounts of nitrogen (primarily ammonia) and (2) by depositing organic matter from ingested phytoplankton and detritus (also includes remnants from ingested auto- and heterotrophic microplankton and zooplankton), which facilitates the benthic recycling of nitrogen. The increased organic loading of sediments from biodeposition may enhance the retention of nutrients coming from both the sea and land in coastal systems and stimulate mineralization and nitrogen release rates (Newell 2004, Nizzoli et al. 2006). Nitrogen fluxes from the recycling of biodeposits trapped within suspended bivalve culture ropes and other structures are also ecologically significant and can be higher than benthic fluxes (Mazouni 2004, Nizzoli et al. 2006, Richard et al. 2006). Accelerated nitrogen cycling and coastal nitrogen retention directly attributed to bivalve excretion and biodeposition may significantly accelerate phytoplankton turnover and production (Doering \& Oviatt 1986, Doering et al. 1989, Asmus \& Asmus 1991, Prins et al. 1995).

Coastal ecosystems are increasingly stressed by many human activities and the potential effects of aquaculture should not be considered in isolation. Significant ecosystem level interactions are expected between bivalve aquaculture and eutrophication (Dame 1996, Cloern 2001, Newell 2004). Applications of agricultural fertilizer to farm lands enrich nutrient concentrations in surface and ground water. Upon reaching coastal systems these nutrients stimulate plant growth and can disrupt the natural balance between the production and metabolism of organic matter. Large populations of bivalve filter-feeders are believed to control coastal ecosystem responses to nutrient loading by ingesting large quantities of microalgae, which increases the estuary's grazing, or 'top down', control of excess phytoplankton biomass (Dame 1996, Cloern 2001, Newell 2004). In addition to potentially having the capacity to clear excess phytoplankton from suspension, bivalve aquaculture may help ameliorate the impacts of nitrogen en- richment in eutrophic coastal waters by removing excess nitrogen in the shellfish harvest (e.g. Rice 2000, 2001). This has led to suggestions that shellfish aquaculture be incorporated into a nutrient trading system as an alternative to nitrogen reduction for improving coastal water quality (Lindahl et al. 2005).

The number of ecosystem processes potentially influenced by bivalve culture and the complexity of their interactions (e.g. simultaneous top down and bottom up controls on phytoplankton) make it difficult to predict the effects of the bivalves on many ecosystem properties. Such predictions are further complicated by ecological interactions between bivalve suspension feeders and eutrophication (Cloern 2001). This study was conducted to further scientific understanding of the nitrogen dynamics of a coastal aquaculture embayment receiving nutrient inputs from land use. Two different approaches were applied to analyzing major elements of the nitrogen cycle: an observation-based nitrogen budget and a dynamic ecosystem model. Results were compared to provide insights into the individual strengths and limitations of each approach with respect to their possible applications. A related objective was to apply these approaches to test hypotheses and refine theories including: (1) the potentially dominant role of mussel aquaculture in nitrogen dynamics at the coastal ecosystem scale; (2) the influence of mussel culture on coastal nutrient retention; and (3) the capacity of the mussel harvest to ameliorate impacts from nitrogen enrichment.

The site used in this study is Tracadie Bay (Fig. 1), one of the more extensively leased mussel aquaculture inlets in Prince Edward Island (PEI; Fig. 1). PEI coastal inlets supply $77 \%$ of the CAD \$ 30 million total value per annum of the mussel culture industry in Canada (DFO 2005). Many PEI embayments, including Tracadie Bay, receive agriculture

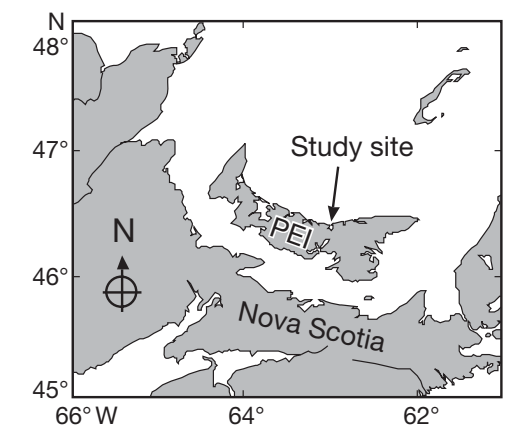

Fig. 1. Prince Edward Island (PEI), Canada; Tracadie Bay (including Winter Harbour) and the distribution of suspended mussel culture leases

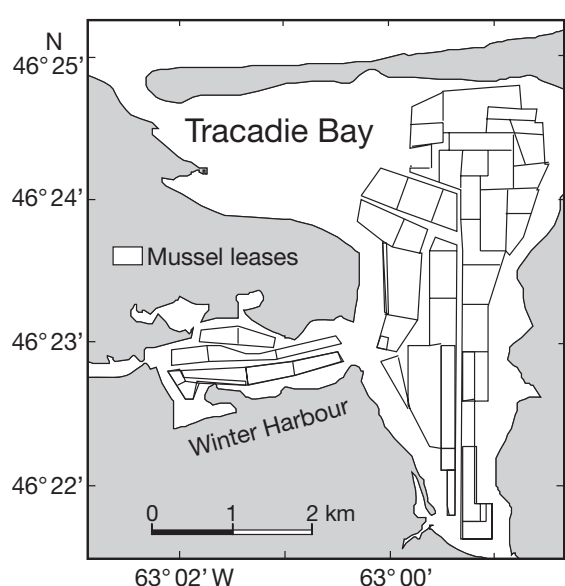

$63^{\circ} 02^{\prime} \mathrm{W}$ $63^{\circ} 00^{\prime}$ 
run-off, and nutrient inputs from fertilizers have resulted in eutrophic conditions (Raymond et al. 2002). Tracadie Bay has been the focus of several studies and extensive field sampling programs have been conducted to document the physical oceanography (Dowd et al. 2001, 2002) and biogeochemistry of the Bay and adjacent waters (e.g. Bates \& Strain 2007). The biophysical control of the distribution of phytoplankton in Tracadie Bay has been examined using a simple tracer model (Dowd 2003), a lower trophic level ecosystem box model (Dowd 2005) and a spatially explicit ecosystem model of seston depletion by the mussel culture (Grant et al. in press). All 3 approaches suggest that mussel grazing strongly affects phytoplankton levels in this inlet, and that the spatial pattern is also dictated by water motion and nitrogen run-off. Dowd (2005) developed an ecosystem box model approach and conducted a preliminary examination of how mussels affect nitrogen cycling in Tracadie Bay. This approach was further refined for this study and applied to quantitatively describe nitrogen dynamics dictated by the major interacting ecosystem components (nutrients, phytoplankton, mussels, detritus and benthos). Detailed biological and chemical field data for Tracadie Bay, which were not available during initial model development, are compared with model output. Whenever possible, actual field data are used in the budget calculations and to determine parameters and initial and boundary conditions for modelling purposes. and land type areas using GIS (ArcInfo v. 9.1). The Tracadie Bay watershed area (Fig. 2) is $146.2 \mathrm{~km}^{2}$ and land types include forest ( $46.8 \%$ of total area), agriculture $(32.7 \%)$, wetlands and beach $(12.5 \%)$, and urban and other $(8.0 \%)$. The Winter River watershed (Fig. 2) is the largest drainage sub-basin to the Bay $\left(69.7 \mathrm{~km}^{2}\right)$ and a relatively large fraction ( $41.4 \%$ ) is used for agriculture (grain, potato, hay and pasture).

Water chemistry. Water samples were collected with Niskin bottles from 1 or $3 \mathrm{~m}$ depths, or both, at 12 stations in Tracadie Bay (circles in Fig. 2) approximately once per month in the ice-free seasons (June to November) for $2 \mathrm{yr}$ (2002 to 2003). Some limited sampling was also conducted through the ice in winter months. Additional nutrient data were available from samples collected in a previous program conducted in 1998 to 1999, which included sampling in the months of July through October. Vertical profiles with a portable CTD (SeaBird 25) provided supporting salinity and temperature data. Dissolved inorganic nutrients were determined for all samples by means of standard autoanalyzer techniques for nitrate and nitrite (Strain \& Clement 1996), and ammonia (Kérouel \& Aminot 1997). In this paper we use 'nitrate' to refer to the total oxidized inorganic nitrogen (nitrate + nitrite), and total inorganic nitrogen (TIN) to refer to nitrate + nitrite + ammonia. Nutrient samples were also collected from 8 stations in the Winter River (squares in Fig. 2) approximately weekly from May to November 2003 by hand dipping sample bottles into the surface layer from shore.

\section{MATERIALS AND METHODS}

Study site. Tracadie Bay (Fig. 1) is a small $\left(16.4 \mathrm{~km}^{2}\right.$ at mean tide and $13.8 \mathrm{~km}^{2}$ at low tide), shallow (mean depth $2.5 \mathrm{~m}$; maximum depth $6 \mathrm{~m}$ ), barrier beach inlet with predominantly diurnal tides having a mean vertical range of $0.6 \mathrm{~m}$. There are currently $6.98 \mathrm{~km}^{2}$ of water column mussel leases in Tracadie Bay (50 and $68 \%$ of the low tide area and volume, respectively) containing a standing stock of approximately $4500 \mathrm{t}$ of mussels (see Fig. 4.3 in Cranford et al. 2006). Annual mussel production is approximately $1900 \mathrm{t}$, or approximately $11 \%$ of the value of the PEI mussel industry.

Information on the Tracadie Bay drainage basin and land use was supplied by the PEI Department of Environment for calculation of drainage basin

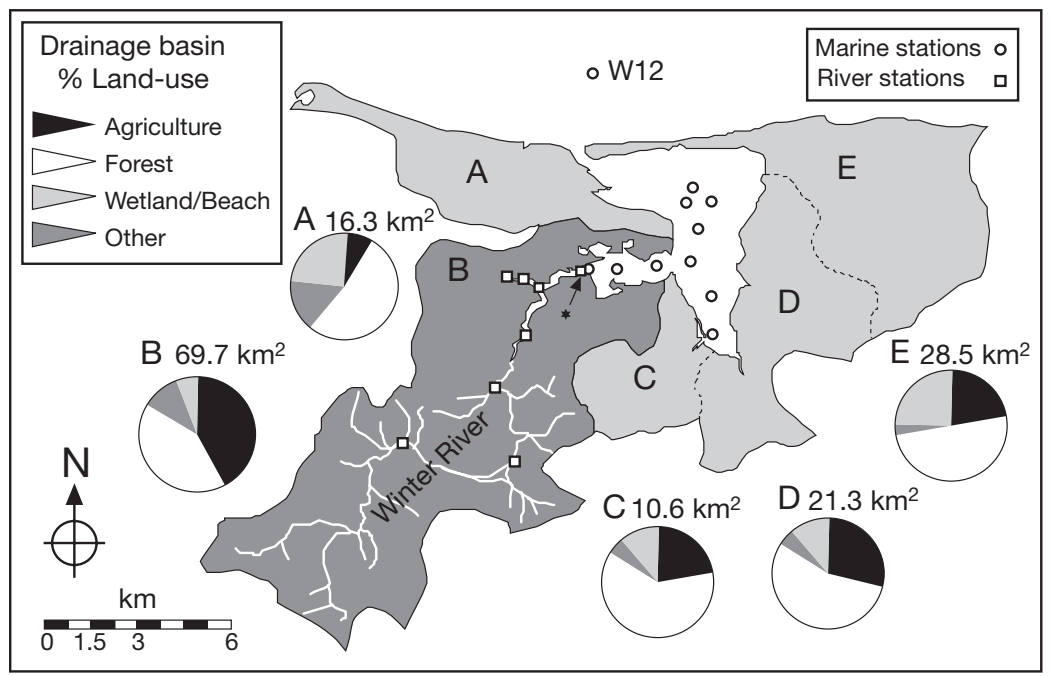

*Water sampling stations: WR1 (left square) and W1 (right circle)

Fig. 2. Tracadie Bay watershed showing the locations of the 5 (A-E) land drainage sub-basins, including the Winter River sub-basin (highlighted region B). Pie charts show the total area and percent land use by categories as identified in the key. Water sampling stations in Winter River (squares) and inside and outside (Stn W12) Tracadie Bay (circles) are shown 
Suspended particulate matter (SPM) in the water samples was collected on $1.7 \mu \mathrm{m}$ nominal pore size glass fibre filters $(25 \mathrm{~mm}$ diameter Micro Filtration Systems type GC). SPM was collected in triplicate on prewashed, precombusted $\left(450^{\circ} \mathrm{C}\right.$ for $\left.4 \mathrm{~h}\right)$, tared glass fibre filters. SPM levels were determined after rinsing the filters under vacuum with isotonic ammonium formate to remove salt, and then drying the filters at $60^{\circ} \mathrm{C}$ and weighing to the nearest $0.01 \mathrm{mg}$. Particulate organic matter (POM) concentration was determined as total weight loss upon ignition at $520^{\circ} \mathrm{C}$ for $6 \mathrm{~h}$ and the organic fraction $\left(f_{\mathrm{POM}}\right)$ was calculated as POM/SPM. Samples from the water sampling surveys described earlier were used to characterize the SPM and organic matter with a moored Water Transfer System (McLane Research Laboratories) that filters water in situ at programmed intervals onto glass fibre filters (47 mm diameter Micro Filtration Systems type GC). This system made it possible to collect frequent SPM samples for the evaluation of $f_{\mathrm{POM}}$. Chl $a$ in SPM samples collected on glass fibre filters (same type as above) during the survey with Niskin bottles was determined from the in vitro fluorescence (Turner Designs fluorometer calibrated against pigment from spinach) of $90 \%$ acetone extracts of the filtered material.

Nitrogen cycle. Table 1 lists the important reservoirs, internal fluxes and external inputs and outputs that are elements of the nitrogen cycle in Tracadie Bay. The letters identifying the reservoirs in Table 1 are used throughout this paper. The TIN reservoir is distinguished from other reservoirs and fluxes expressed in nitrogen equivalents. Table 1 also shows which components are quantified in the nitrogen budget and modelling approaches.

Whenever possible, we have used field data for constructing the nitrogen budget and for setting boundary and initial conditions for the models and assessing their performance. For many such purposes we synthesized the available field data and produced seasonal cycles (monthly) using objective analysis. Objective analysis is sometimes referred to as an 'optimal estimator' because the Gauss-Markov theorem, on which it is based, claims that: 'Given the statistics of the field being measured and the noise levels involved, no other [linear] analysis could perform better' (Bretherton et al. 1976).

To characterize the nitrogen cycle, we required estimates of the nitrogen levels in the phytoplankton (P), dissolved nutrients (TIN) and detritus (D) reservoirs within Tracadie Bay and for the offshore. We formulated both the nitrogen budget and the models to use a common currency for the different ecosystem reservoirs and fluxes, expressing all quantities in nitrogen equivalents. For many quantities we use units of
Table 1. Elements of the nitrogen cycle in Tracadie Bay. Quantities calculated or predicted by each model are indicated by ' $y$ ' and those not considered by ' $n$ '

\begin{tabular}{|c|c|c|c|}
\hline Symbol & Description & $\mathrm{N}$ budget & $\begin{array}{c}\text { Lower trophic } \\
\text { level model }\end{array}$ \\
\hline \multicolumn{4}{|l|}{ Reservoirs } \\
\hline $\mathrm{P}$ & Phytoplankton & y & $\mathrm{y}$ \\
\hline TIN & \multicolumn{2}{|c|}{ Inorganic nitrogen $\mathrm{y}$} & $\mathrm{y}$ \\
\hline $\mathrm{D}$ & \multicolumn{2}{|l|}{ Detritus } & $\mathrm{y}$ \\
\hline B & \multicolumn{2}{|l|}{ Benthos } & $\mathrm{y}$ \\
\hline M & \multicolumn{2}{|l|}{ Cultured mussels } & Specified \\
\hline \multicolumn{4}{|l|}{ Internal fluxes } \\
\hline $\mathrm{TIN} \rightarrow \mathrm{P}$ & \multirow{3}{*}{$\begin{array}{l}\text { Photosynthesis } \\
\text { Mortality } \\
\text { Remineralization } \\
\text { (water column) }\end{array}$} & $\mathrm{n}$ & $\mathrm{y}$ \\
\hline $\mathrm{P} \rightarrow \mathrm{D}$ & & $\mathrm{n}$ & $\mathrm{y}$ \\
\hline $\mathrm{D} \rightarrow \mathrm{TIN}$ & & $\mathrm{n}$ & y \\
\hline $\mathrm{B} \rightarrow \mathrm{TIN}$ & $\begin{array}{l}\text { Remineralization } \\
\text { (benthos) }\end{array}$ & $\mathrm{n}$ & $\mathrm{y}$ \\
\hline $\mathrm{D} \rightarrow \mathrm{B}$ & Sedimentation & $\mathrm{n}$ & $\mathrm{y}$ \\
\hline $\mathrm{B} \rightarrow \mathrm{D}$ & Resuspension & $\mathrm{n}$ & $\mathrm{y}$ \\
\hline $\mathrm{P} \rightarrow \mathrm{M}$ & Ingestion & y & $\mathrm{y}$ \\
\hline $\mathrm{D} \rightarrow \mathrm{M}$ & Ingestion & $\mathrm{y}$ & $\mathrm{y}$ \\
\hline $\mathrm{M} \rightarrow \mathrm{B}$ & Biodeposition & $\mathrm{y}$ & $\mathrm{y}$ \\
\hline $\mathrm{M} \rightarrow \mathrm{TIN}$ & Excretion & $\mathrm{y}$ & $\mathrm{y}$ \\
\hline \multicolumn{4}{|l|}{ External fluxes } \\
\hline \multicolumn{2}{|l|}{ Mussel harvest } & y & $\mathrm{y}$ \\
\hline River & $\begin{array}{l}\text { Winter River } \\
\text { discharge }\end{array}$ & TIN only $^{\mathrm{a}}$ & TIN only ${ }^{\mathrm{a}}$ \\
\hline Offshore & $\begin{array}{l}\text { Marine } \\
\text { exchange }\end{array}$ & $\begin{array}{l}\text { P, TIN } \\
\text { and D }\end{array}$ & $\begin{array}{l}\text { P, TIN } \\
\text { and D }\end{array}$ \\
\hline Burial & & $\mathrm{n}$ & $\mathrm{y}$ \\
\hline Atmospheric & Denitrification & $\mathrm{n}$ & $\mathrm{n}$ \\
\hline
\end{tabular}

tonnes nitrogen or tonnes nitrogen per year (t $\mathrm{N}$ or $\mathrm{t} \mathrm{N} \mathrm{yr}^{-1}$ ). P was determined from the chl a distribution, converted to nitrogen using a carbon:chl a ratio of 50:1, and a Redfield C:N ratio of 106:16 (molar) in the phytoplankton. The TIN values require no conversion, but require summing the nitrate and ammonia concentrations. The detritus is considered to be the fraction of organic matter not associated with living phytoplankton cells. Since most of the living cells in the water column are phytoplankton, the amount of nitrogen in detritus $\left(\mathrm{N}_{\mathrm{D}}\right)$ can be calculated from the difference between nitrogen in the total particulate organic matter $\left(\mathrm{N}_{\mathrm{POM}}\right)$ and the nitrogen in the phytoplankton $\left(\mathrm{N}_{\mathrm{P}}\right)$ :

$$
\mathrm{N}_{\mathrm{D}}=\mathrm{N}_{\mathrm{POM}}-\mathrm{N}_{\mathrm{P}}
$$

$\mathrm{N}$ in bacteria, either free-living in the water column or associated with detritus, is not considered in these calculations. 
For areas inside Tracadie Bay we have sufficient data for POM and P to calculate $\mathrm{N}_{\mathrm{D}}$. $\mathrm{P}$ is converted to $\mathrm{N}_{\mathrm{P}}$ as described previously; $\mathrm{N}_{\mathrm{POM}}$ is calculated using the Redfield C:N ratio and 1.9:1 as a typical ratio of organic matter:organic carbon. These $\mathrm{N}_{\mathrm{D}}$ values were then objectively analyzed in the same way as the other parameters. However, the extra steps in the calculation add to the uncertainty of the resulting seasonal cycle. For the offshore station, sufficient POM data are not available for this calculation. Instead, we have used the observation that $\mathrm{N}_{\mathrm{P}}+\mathrm{N}_{\mathrm{D}}$ is approximately constant $(\sim 6.4 \mu \mathrm{M} \mathrm{N})$ in data from the Tracadie Bay area to approximate offshore D from the offshore seasonal cycle of P. Although the determination of the nitrogen in both $\mathrm{P}$ and $\mathrm{D}$ are operational, they are internally consistent because the same filters to collect SPM were used in both measurements.

$\mathrm{P}$, TIN and D levels in offshore waters influencing Tracadie Bay are boundary conditions required for both the nitrogen budget and the models. Seasonal cycles for these quantities were predicted by objective analysis for the offshore region using both data from this study at Stn W12 (Fig. 2) and data from the BioChem data archive maintained by the Department of Fisheries and Oceans for adjacent areas of the Magdalen Shallows in the Gulf of St. Lawrence. Concentrations were predicted for $5 \mathrm{~m}$ depth at Stn W12 for the middle of each month. Julian day is used for the time axis (i.e. data from all years are merged) and the data set is expanded to cover the range 0 to $365 \pm 182 \mathrm{~d}$ to avoid biasing estimates at each end of the calendar year. Fig. 3 shows one such seasonal cycle predicted for nitrate at Stn W12 and the distribution of data points on which it is based ( 1400 measurements). The corresponding seasonal cycles for ammonia and

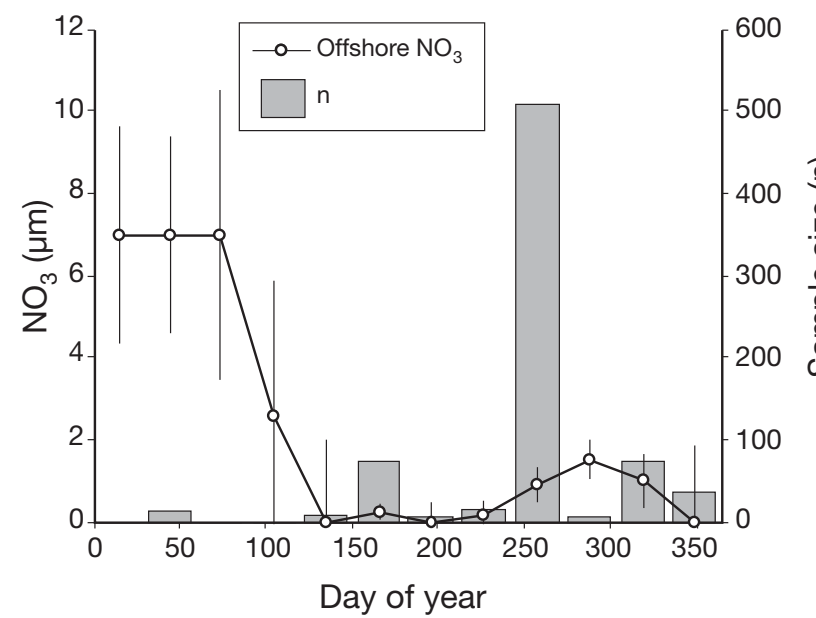

Fig. 3. Curve: Seasonal cycle of nitrate in waters offshore from Tracadie Bay (Stn W12). Error bars: $\pm 1 \sigma$ associated with each monthly prediction. Histogram bars: monthly distribution of data points available for predicting the seasonal cycle chlorophyll were also determined (not shown), and these cycles were used to calculate seasonal cycles for P, TIN and $\mathrm{D}$ in nitrogen equivalents as previously described.

Objective analysis was also used to estimate seasonal cycles for areas within Tracadie Bay for comparison with model predictions and for calculating mean nitrogen inventories for the nitrogen budget. Estimates have been made for each box used in the model described below. For these analyses, the seasonal cycle was predicted for each point on a $200 \mathrm{~m}$ grid in Tracadie Bay. Data for each month for each point in each model box were then averaged to produce a seasonal cycle for the model box. For example, Fig. 4 shows the predicted chlorophyll cycle for the boxes of the lower trophic level model.

The seasonal cycles predicted in this way for both the offshore and the model boxes within Tracadie Bay describe conditions that are averaged over all the available data and do not describe a specific year's annual cycle. The temporal and spatial distributions of these data vary between the different model boxes and the offshore. Some gaps in the sampling exist, such as during the spring due to ice break-up. This limitation is most serious with TIN, for which the few available winter measurements are highly variable $(7$ to $150 \mu \mathrm{M})$ with a mean value $(52 \mu \mathrm{M})$ that is much higher than observed at other times of year. Although all these estimates are based on data, they are still idealized representations of the annual cycle.

Lower trophic level model. Dowd (2005) developed a lower trophic level ecosystem model for Tracadie Bay, implemented with 3 spatial boxes (Fig. 5), that predicts the levels of phytoplankton (P), zooplankton, dissolved nutrients (TIN) and detritus (D), as well as their interactions with a simplified benthos (B) that

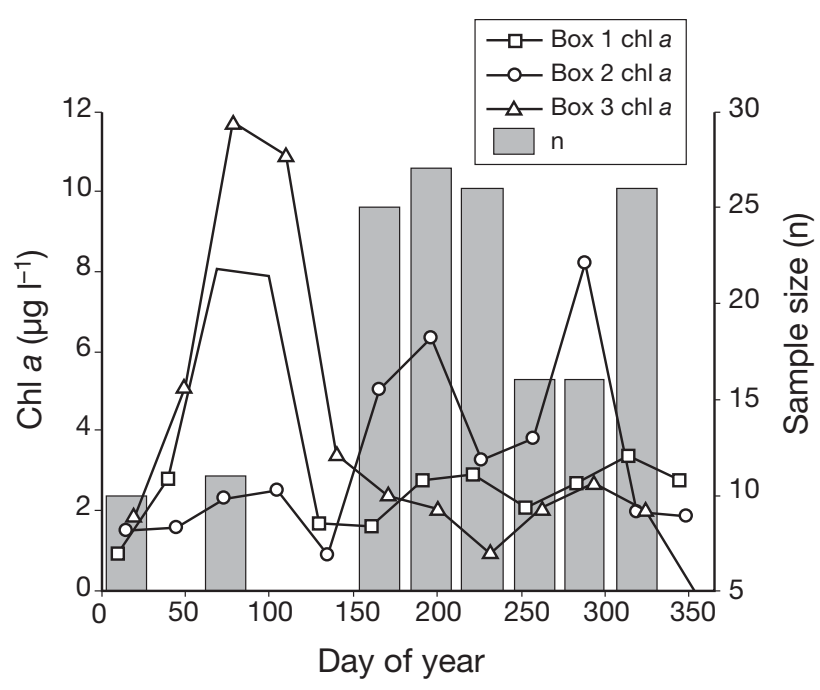

Fig. 4. Seasonal chlorophyll cycles predicted for the 3 boxes of the lower trophic level model and the distribution of data used to make these estimates 


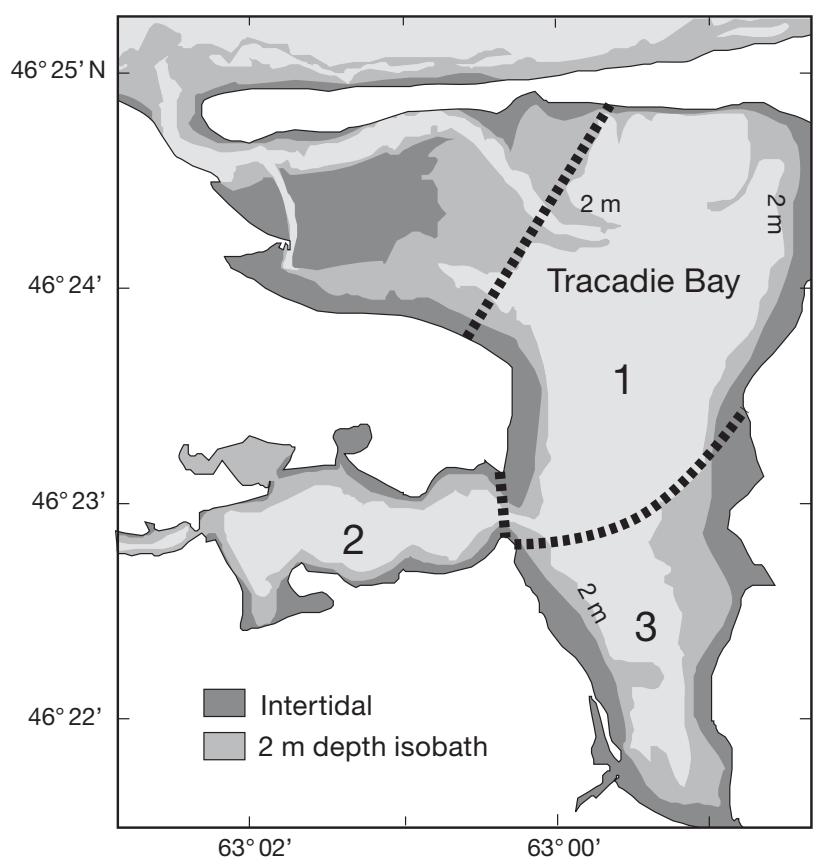

Fig. 5. Tracadie Bay showing the 3 boxes and boundaries used in the lower trophic level model. The intertidal and $2 \mathrm{~m}$ depth contours are also shown

includes terms for particle settling, permanent burial, resuspension and nutrient remineralization. Water exchange coefficients were derived from a heat budget calculation using observed temperature time series. The effects of mussel aquaculture (M) are evaluated by superimposing the grazing activity of the mussels onto this system. The elements of the nitrogen cycle described by the model are listed in Table 1. As used in this study, the model formulation differs from that of Dowd (2005) in the following ways:

(1) The units have been converted to nitrogen equivalents.

(2) Since tests showed that the zooplankton pelagic state variable $(Z)$ had little impact on the nitrogen dynamics, it has been eliminated. Ecosystem closure is achieved by a quadratic loss term $\lambda_{\mathrm{p}} \mathrm{P}^{2}$ that represents mortality and grazing of phytoplankton. This loss term is put back into the detritus pool, resulting in the following equation for P (which replaces Eq. 1 in Dowd 2005):

$$
\frac{\mathrm{dP}}{\mathrm{d} t}=f\left\{\mathrm{~N}_{i} \mathrm{k}_{\mathrm{n}}\right\} \gamma_{\mathrm{p}} \mathrm{P}-\lambda_{\mathrm{p}} \mathrm{P}^{2}-\mathrm{I}_{\mathrm{m}} \mathrm{P}+\mathrm{K}\left(\mathrm{P}_{\infty}-\mathrm{P}\right)
$$

(see Table 2 for definiton of terms). The corresponding zooplankton terms have been dropped from the equations for $\mathrm{N}$ and D (Eqs. 3 \& 4 in Dowd 2005). Eq. (4) in Dowd (2005) was also adjusted for the flux from P. The model formulation for B (Eq. 5 in Dowd 2005) remains unchanged.
(3) The convolution integral that governed benthic remineralization has been replaced with a simple temperature and B dependent efflux (rather than being based on the weighted time history of the input flux).

(4) The external $\mathrm{N}$ source has been replaced with a seasonally variable freshwater $\mathrm{N}$ source term (i.e. river inputs, land runoff); see next section for more details. This source is input into Box 2 (Winter Harbour; Fig. 5).

(5) Mussel grazing, $I_{m}$ is partitioned amongst the boxes to correspond with present conditions. Winter Harbour has no grazing (primarily a mussel spat collection site) and $I_{m}$ values for the other 2 boxes have been determined from the nitrogen budget of the cultured mussel population (see next section).

Annual nitrogen budget. The average annual nitrogen inventories in Tracadie Bay reservoirs were calculated as follows. $\mathrm{N}_{\mathrm{P}}$ was calculated using the seasonal cycle of $\mathrm{P}$ concentrations estimated from the objective analysis and the water volumes of the Bay (same procedure as described above for the boxes used in the lower trophic level model). Nitrogen in the farmed mussel biomass was estimated based on a total harvested biomass of approximately $1900 \mathrm{t}$ wet weight (shell included). This biomass value does not account for mussel mortality, drop-off, or discarding of damaged or undersize mussels during harvest. Estimates based on industry lease reporting place the biomass of mussels in the Bay at approximately $4500 \mathrm{t}$ (Cranford et al. 2006). The nitrogen in mussel tissue (excluding shell) was estimated using a typical fraction of wet meat to total weight of $40 \%$, a water content of the meat of $85.5 \%$ (P. J. Cranford unpubl. data for Tracadie Bay) and average nitrogen content of $7.79 \%$ (Smaal \& Vonck 1997).

The amount of phytoplankton and detritus nitrogen consumed by mussels depends on the rate at which mussels filter water (i.e. their clearance rate) and the nitrogen content of the suspended particulate matter in the water column. Clearance rate depends primarily on the size of the mussels. We used a linear growth model to estimate the average monthly size of Tracadie Bay mussels over a 24 mo grow-out period to $0.7 \mathrm{~g}$ dry weight at harvest. Meat weight trajectories in Tracadie Bay vary each year (Waite et al. 2005) and the linear function represents average conditions. The clearance rate $(C)$ for each mussel was calculated for each month using the allometric equation of Smaal et al. (1997), which is based on similar natural dietary conditions as found in Tracadie Bay. Monthly ingestion rates were calculated by multiplying $C$ by the estimated number of mussels in the harvest $\left(161 \times 10^{6}\right)$ and the average SPM-N concentration $\left(2.5 \mathrm{mg} \mathrm{SPM}^{-1} \times 0.04=0.10 \mathrm{mg}\right.$ $\mathrm{N}^{-1}$ ). Nitrogen ingestion was summed over the $24 \mathrm{mo}$ period to estimate annual ingestion. Summing monthly estimates from a single cohort over a $2 \mathrm{yr}$ period is 
equivalent to the actual situation where 2 cohorts (Age 1 and Age 2) are present in the Bay each year. To estimate how much of the nitrogen in ingested food is derived from phytoplankton and detritus, we assumed $f_{\text {POM }}$ values of 0.8 and 0.2 , respectively, for each food resource. Using the mean SPM value of $2.5 \mathrm{mg} \mathrm{l}^{-1}$ and an average annual seston $f_{\mathrm{POM}}$ value of 0.30 ( $\mathrm{SD}=0.14$, $\mathrm{n}=80$; from the 2003 Niskin bottle and in situ water sampling survey), we estimate that approximately $40 \%$ of ingested seston organic matter originates from phytoplankton. A similar proportion may be expected for nitrogen ingestion. At the relatively low SPM concentrations found in Tracadie Bay the limited production of pseudofaeces does not significantly affect ingestion or biodeposition estimates (Smaal et al. 1997, Cranford \& Hill 1999) and is not considered here.

The amount of nitrogen in the faeces produced by the mussels can be determined from the difference between the nitrogen ingested and the nitrogen absorbed by the mussels. The latter depends on the absorption efficiency (AE) of the ingested food, which is in turn dependent on the concentration of organic matter in the SPM $\left(f_{\text {POM }}\right)$. We estimated AE based on an empirical relationship between $\mathrm{AE}$ and $f_{\mathrm{POM}}$ :

$$
\mathrm{AE}=0.85\left(1-\mathrm{e}^{-5 \cdot\left(f_{\mathrm{POM}}{ }^{-0.2}\right)}\right)
$$

derived from data reported for Mytilus edulis by Cranford \& Hill (1999) and Figueiras et al. (2002). The average annual $f_{\text {POM }}$ value of 0.30 (above) resulted in an $\mathrm{AE}$ value of 0.33 . Absorption rate was then calculated as the product of $\mathrm{AE}$ and nitrogen ingestion rate, and faeces production rate was calculated as ingestion rate minus absorption rate.

The annual excretion of nitrogen by mussels was estimated using 2 approaches. First, data presented in Hawkins \& Bayne (1985) showed that, on average, $34 \%$ of absorbed nitrogen (calculated in previous paragraph) is excreted by mussels. Second, the allometric equation from Smaal et al. (1997) was used to estimate the excretion of $\mathrm{NH}_{4}-\mathrm{N}$ by different size classes of mussels in the same way as described above for estimating $\mathrm{N}$ ingestion. Most of the excreted nitrogen is in the form of dissolved ammonia.

Freshwater inputs used in the nitrogen budget are based on monthly averaged freshwater flow data for Winter River during 1968 to 2004, obtained from the Environment Canada hydrometric database (www.wsc.ec.gc.ca) for the station near Suffolk $\left(46^{\circ} 19^{\prime} 56^{\prime \prime} \mathrm{N}, 36^{\circ} 3^{\prime} 53^{\prime \prime} \mathrm{W} ; 37.5 \mathrm{~km}^{2}\right.$ drainage area). Average flow rate measurements from this station were adjusted by watershed areas not gauged to estimate the total monthly freshwater outflow from Winter River and the total freshwater run-off from all drainage sub-basins to Tracadie Bay. Data on nutrient concen- trations from 2 sampling stations (surface water at Stn WR1 and from $1 \mathrm{~m}$ depth at Stn W1) located near the mouth of Winter River (Fig. 2), supplemented by estimates of levels during the winter months for similar environments, were used along with the flow data for estimating TIN fluxes in freshwater flowing into Tracadie Bay.

Exchanges of nitrogen between Tracadie Bay and the offshore were estimated from the tidal volume of the Bay and the concentrations of materials of interest in inflowing and outflowing waters. The seasonal cycles for P, TIN and D were estimated for the northern part of Tracadie Bay (defined as Box 1 of the lower trophic level model; Fig. 5) and for offshore waters to characterize the outflow and inflow, respectively. These data were combined with an estimate of 1.17 tidal volumes per day to yield gross estimates of nitrogen export and import for each parameter. The number of tidal volumes per day was based on assessing flushing times for the Bay by fitting a harmonic that describes the 3 major components of the mixed tide (the $\mathrm{O}_{1}$ and $\mathrm{K}_{1}$ diurnal and the $\mathrm{M}_{2}$ semi-diurnal) to spring and neap tides.

\section{RESULTS}

\section{Nitrogen budget}

Estimates for the average nitrogen inventories in Tracadie Bay and the internal and external annual nitrogen fluxes are shown schematically in Fig. 6A.

\section{Reservoirs}

We estimated an annual $\mathrm{P}$ inventory in Tracadie Bay of $1.2 \mathrm{t}$ of nitrogen. The equivalent inventory of TIN is $13 \mathrm{t} \mathrm{N}$, and for detritus is $3.0 \mathrm{t} \mathrm{N}$. The inventory of nitrogen in mussel tissues in the Bay was estimated at 20 t N, with $9 \mathrm{t} \mathrm{N} \mathrm{yr}^{-1}$ removed annually in the mussel harvest. Our confidence in the former value is relatively low, so the $\mathrm{N}$ budget (and the lower trophic level model) only considers the influences of a mussel biomass equal to the $9 \mathrm{t} \mathrm{N} \mathrm{yr}^{-1}$ harvest (Fig. 6A), for which there was reliable data. The mussels harvested each year are estimated to ingest $230 \mathrm{t} \mathrm{N} \mathrm{yr}^{-1}$, with $92 \mathrm{t} \mathrm{N} \mathrm{yr}^{-1}$ originating directly from phytoplankton consumption. To the extent that this calculation does not include a large, but poorly quantified, standing stock of cultured or wild mussels, this ingestion rate should be interpreted as a lower limit. Applying a known relationship for the absorption of organic matter by Mytilus edulis resulted in estimates for absorption and faeces production rates of 76 and $154 \mathrm{t} \mathrm{N} \mathrm{yr}^{-1}$, 

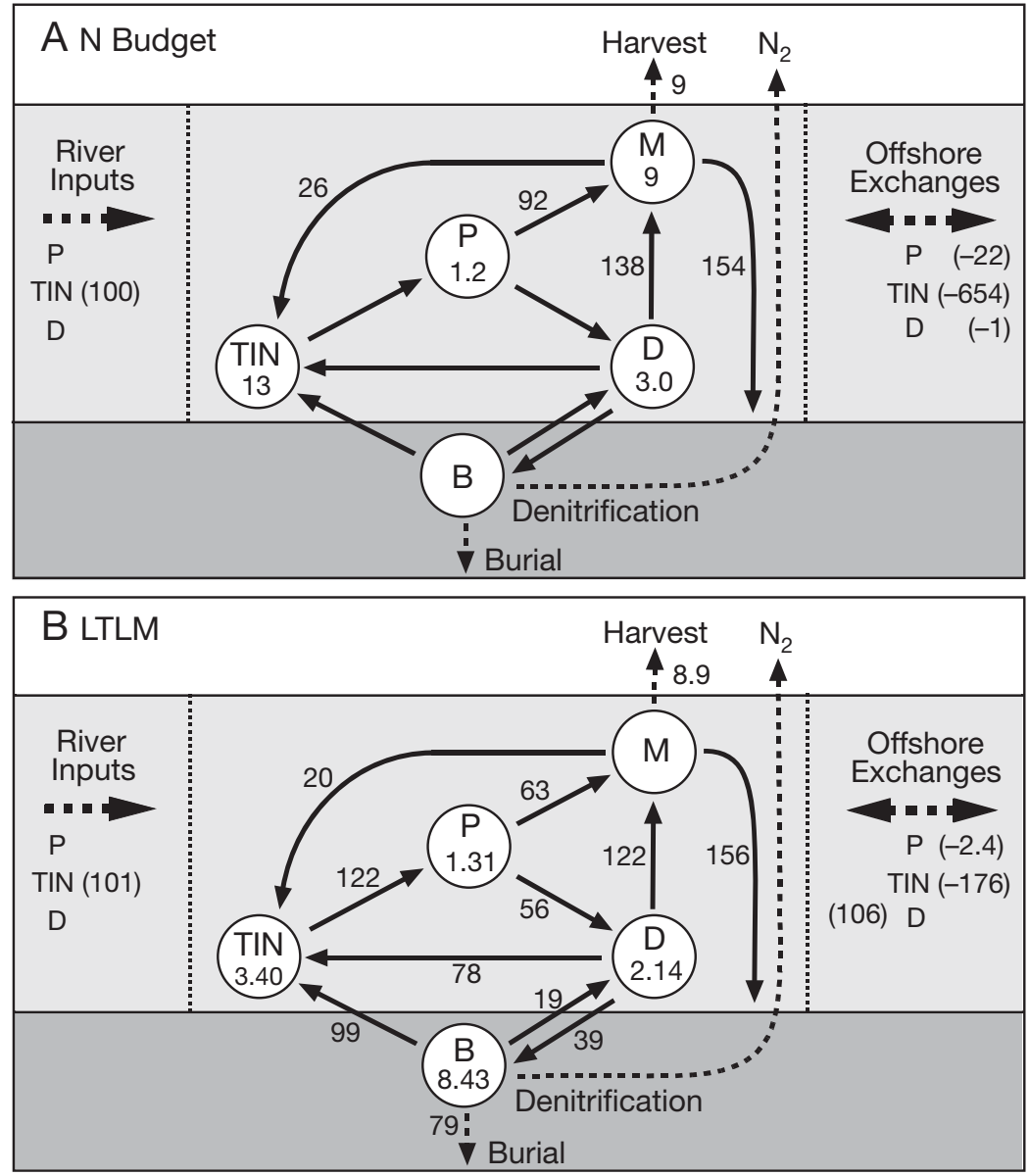

Fig. 6. Nitrogen reservoir inventories and flux pathway in Tracadie Bay calculated from (A) the nitrogen budget, and (B) the 'cumulative effects' scenario (present conditions) of the lower trophic level model (LTLM). Both approaches are for a mussel population equal to the annual mussel harvest. $\mathrm{P}=$ phytoplankton, $\mathrm{TIN}=$ inorganic nitrogen, $\mathrm{D}=$ detritus, $\mathrm{B}=$ benthos, $\mathrm{M}=$ mussels . Solid arrows represent internal fluxes and dashed arrows are external inputs and outputs. Inventories in reservoirs are annual averages ( $\mathrm{N}$ ) and all other quantities are annual fluxes $\left(\mathrm{t} \mathrm{N} \mathrm{yr}^{-1}\right)$. For external fluxes, positive numbers represent gains to Tracadie Bay and negative numbers are losses

trations at the mouth of Winter River with monthly water flows to Tracadie Bay yielded an estimate of $88 \mathrm{t} \mathrm{N}$ $\mathrm{yr}^{-1}$ for the annual freshwater input of TIN. This estimate assumes that the water samples collected from the surface layer had zero salinity (salinity data are not available for these samples). Since TIN concentrations in Winter River are much higher than those in Tracadie Bay or offshore in the Gulf of St. Lawrence, this estimate is a lower limit with respect to the presence of some saltwater in the samples. The sub-surface (1 $\mathrm{m}$ depth) samples collected at the adjacent sampling site (W1) had an average salinity of $27.1 \mathrm{psu}$. The freshwater concentrations corresponding to the W1 samples were estimated using a 2-component mixing model, the average salinity (28.9 psu) at $15 \mathrm{~m}$ depth at the offshore station (W12) and the monthly average TIN levels at W12 determined from the objective analysis of offshore data as described previously. The corresponding TIN fluxes based on these data are equivalent to an annual flux of $124 \mathrm{t} \mathrm{N} \mathrm{yr}^{-1}$.

These 2 data-based estimates for the TIN flux can be compared to one based on land use. Frink (1991) reviewed export coefficients for nutrients from watersheds to estuaries and derived a model that predicted $\mathrm{N}$ coefficients $( \pm \mathrm{SE})$ for agricultural, forested and urban land types of $7.6 \pm$ $2.2,2.4 \pm 0.5$ and $13.4 \pm 2.6 \mathrm{~kg} \mathrm{~N}$ $\mathrm{ha}^{-1} \mathrm{yr}^{-1}$, respectively. Combining

respectively. Our 2 estimates for nitrogen excretion provided comparable results, with $26 \mathrm{t} \mathrm{N} \mathrm{yr}^{-1}$ calculated based on the typical proportion of absorbed $\mathrm{N}$ that is excreted, and $23 \mathrm{t} \mathrm{N} \mathrm{yr}^{-1}$ derived by applying the allometric equation of Smaal et al. (1997).

\section{Freshwater inputs}

Monthly freshwater flows from Winter River between 1964 and 2004 averaged between 0.5 (August to September) and $3.0 \mathrm{~m}^{3} \mathrm{~s}^{-1}$ (April), with an annual mean of $1.2 \mathrm{~m}^{3} \mathrm{~s}^{-1}$. Scaling these flows to the remaining Tracadie Bay watershed gave an average annual freshwater input of $2.6 \mathrm{~m}^{3} \mathrm{~s}^{-1}$ (coefficient of variation $[\mathrm{CV}]=0.21$ ). Combining monthly average $\mathrm{N}$ concen- these numbers with the corresponding land-use areas yields an average flux of $69 \mathrm{t} \mathrm{N} \mathrm{yr}^{-1}$ from the Tracadie Bay watershed with a predicted range from 52 to $86 \mathrm{t} \mathrm{N} \mathrm{yr}{ }^{-1}$. Export of nitrogen from wetland areas was assumed to be minimal since they act as $\mathrm{N}$ sinks (i.e. denitrification, sedimentation and plant uptake).

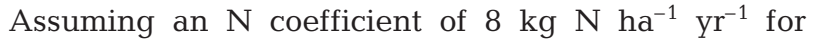
atmospheric deposition (Frink 1991), the beach areas would contribute approximately an additional $8 \mathrm{~kg} \mathrm{~N}$ $\mathrm{yr}^{-1}$ giving a total predicted TIN flux of $76 \mathrm{~kg} \mathrm{~N} \mathrm{yr}^{-1}$. The 3 estimates of total TIN inputs to Tracadie Bay are reasonably consistent. For discussion purposes we use a value of $100 \mathrm{t} \mathrm{N} \mathrm{yr}^{-1}$ in our $\mathrm{N}$ budget, which is based on the extensive Winter River measurements (flow and nutrient concentrations) and includes some correction for nutrient dilution in river mouth samples 
by seawater. TIN input from agriculture is estimated to

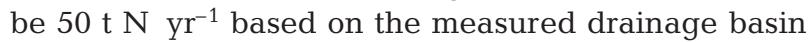
land use and the above export coefficient for agriculture land. Particulate nitrogen fluxes from land run-off are probably much less than the TIN fluxes and have been assumed negligible in our budget.

\section{Offshore exchanges}

Combining the seasonal cycles of phytoplankton (P) in outflowing (northern Tracadie Bay) and inflowing (offshore) water with the daily tidal flushing volume

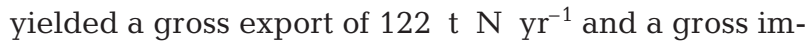
port at $100 \mathrm{t} \mathrm{N} \mathrm{yr}^{-1}$, which results in a net export of $22 \mathrm{t} \mathrm{N} \mathrm{yr}^{-1}$. For TIN, gross export was $836 \mathrm{t} \mathrm{N} \mathrm{yr}^{-1}$ and gross import was 183 t $\mathrm{N} \mathrm{yr}^{-1}$ giving a net export of $654 \mathrm{t} \mathrm{N} \mathrm{yr}^{-1}$. Tracadie Bay is a net exporter of TIN in all months except January and November. The high winter TIN levels in Tracadie Bay contribute substantially to the large net export. For detritus (D) gross export was estimated to be $275 \mathrm{t} \mathrm{N} \mathrm{yr}{ }^{-1}$ and gross import was $274 \mathrm{t} \mathrm{N} \mathrm{yr}^{-1}$ with a net export of $1 \mathrm{t} \mathrm{N} \mathrm{yr}{ }^{-1}$. cycle for the ecosystem state variables. A spin-up period of 2 yr ensured the system (mainly B) was in a statistical steady state. Stochastic resuspension implies that the system will not repeat exactly from year to year and so annual fluxes may not exactly balance.

Some of the calculations for the mussel portion of the nitrogen budget are also used to set parameters in the lower trophic level model. The model requires estimates for the total filtration rate of the mussel population and the fractions of ingested nitrogen that are harvested or excreted. Clearance rate of the annually harvested mussel biomass ( $9 \mathrm{t} \mathrm{N} \mathrm{yr}^{-1}$ ) was determined during the ingestion rate calculation (described previously). Summing the clearance rate over all size classes yields a total filtration rate of $6.3 \times 10^{6} \mathrm{~m}^{3} \mathrm{~d}^{-1}$. Although detailed stocking information that would allow calculation of the numbers of mussels in each model box is not available, using the leased areas known to support mussel grow-out (as opposed to leases used for spat collection) as proxies allocates $\sim 92 \%$ of the mussels to Box $1, \sim 1 \%$ to Box 2 , and $\sim 7 \%$ to Box 3 . Scaling the total filtration rate to the volume of each box using these mussel densities produces ingestion rate $I_{m}$

\section{Lower trophic level model}

\section{Model inputs and parameters}

The variables, parameters and inputs to the model are summarized in Table 2. Computation of the maximum light limited phytoplankton growth rate, $\lambda_{p}(t)$, was based on a photosynthesis-irradiance $(\mathrm{P}-\mathrm{I})$ relationship with the maximum photosynthetic rate modulated by temperature. A carbon to chl a ratio of 50:1 was used to convert the P-I relationship to a growth rate (see Dowd 2005). Daily values for the far field concentrations of $\mathrm{P}_{\infty}(\mathrm{t})$, $\mathrm{N}_{\infty}(\mathrm{t})$ and $\mathrm{D}_{\infty}(\mathrm{t})$, and for nitrogen inputs, $\mathrm{N}_{\text {in }}(\mathrm{t})$, into Winter Harbour (Box 2) were derived using the objective analysis results described above. Values used for the $\mathrm{N}$ pool were total inorganic nitrogen $($ TIN $=$ nitrate + nitrite + ammonia). Detritus inputs, $\mathrm{D}_{\text {in }}(\mathrm{t})$, due to freshwater inputs and internal sources such as the decay of macrophytes are essentially unknown and not considered; however, the model is not particularly sensitive to changes in this forcing term (Dowd 2005). The model was run to produce an annual
Table 2. Definition of quantities in the lower trophic level model. Groupings are according to variable type. For each quantity the following information is given: units, unit numerical value (or its source) and a brief definition. Explicit functional dependence on time $(\mathrm{t})$ or temperature $(\mathrm{T})$ is indicated. $\mathrm{P}=$ phytoplankton, $\mathrm{TIN}=$ inorganic nitrogen, $\mathrm{D}=$ detritus, $\mathrm{B}=$ benthos and $\mathrm{M}=$ mussels . Other symbols are defined in Dowd (2005)

\begin{tabular}{|c|c|c|c|}
\hline Quantity & Units & Value & Definition \\
\hline \multicolumn{4}{|c|}{ State variables } \\
\hline $\mathrm{P}$ & $\mathrm{mmol} \mathrm{N} \mathrm{m}^{-3}$ & See text & Phytoplankton \\
\hline $\mathrm{N}$ & $\mathrm{mmol} \mathrm{N} \mathrm{m}^{-3}$ & See text & Nutrients \\
\hline $\mathrm{D}$ & $\mathrm{mmol} \mathrm{N} \mathrm{m}^{-3}$ & See text & Water column detritus \\
\hline B & $\mathrm{mmol} \mathrm{N} \mathrm{m}^{-2}$ & See text & Benthic detritus \\
\hline \multicolumn{4}{|c|}{ Parameters } \\
\hline $\mathrm{K}$ & $d^{-1}$ & Dowd (2005) & Exchange/flushing coefficient \\
\hline $\mathrm{k}_{\mathrm{n}}$ & $\mathrm{mmol} \mathrm{N} \mathrm{m}^{-3}$ & 2.5 & Half-saturation for $\mathrm{N}$ uptake by $\mathrm{P}$ \\
\hline$\gamma_{\mathrm{p}}(\mathrm{t})$ & $0.2-1$ & $\begin{array}{c}\text { Eq. (8), } \\
\text { Dowd (2005) }\end{array}$ & P growth rate \\
\hline$\lambda_{\mathrm{p}}$ & $\mathrm{mmol} \mathrm{N} \mathrm{m} \mathrm{m}^{-3} \mathrm{~d}^{-1}$ & 0.05 & Grazing loss of $\mathrm{P}$ \\
\hline$\varphi_{\mathrm{d}}(\mathrm{T})$ & $d^{-1}$ & $0.02-0.1$ & Remineralization rate of $\mathrm{D}$ to $\mathrm{TIN}$ \\
\hline$\lambda_{\mathrm{d}}$ & $d^{-1}$ & 0.05 & Sinking rate for $\mathrm{D}$ \\
\hline$\varphi_{\mathrm{b}}(\mathrm{T})$ & $d^{-1}$ & 0.01 & Remineralization rate of $\mathrm{B}$ to TIN \\
\hline $\mathrm{r}(\mathrm{t})$ & $\operatorname{mmol~} \mathrm{N} \mathrm{m}^{-3} \mathrm{~d}^{-1}$ & Variable & Resuspension flux \\
\hline$\alpha$ & - & 0.01 & Burial fraction \\
\hline $\mathrm{I}_{\mathrm{m}}$ & $d^{-1}$ & See text & Ingestion rate of bivalves \\
\hline$\varepsilon_{\mathrm{m}}$ & - & 0.065 & Assimilated fraction for bivalves \\
\hline$\beta_{\mathrm{m}}$ & - & 0.11 & Excreted fraction for bivalves \\
\hline$\eta$ & $\mathrm{m}$ & 4 & Water depth \\
\hline \multicolumn{4}{|c|}{ External inputs } \\
\hline $\mathrm{P}_{\infty}(\mathrm{t})$ & $\mathrm{mmol} \mathrm{N} \mathrm{m}^{-3}$ & See Fig. 7 & Far field $\mathrm{P}$ \\
\hline $\mathrm{N}_{\infty}(\mathrm{t})$ & $\mathrm{mmol} \mathrm{N} \mathrm{m}^{-3}$ & See Fig. 8 & Far field TIN \\
\hline$D_{\infty}(t)$ & $\mathrm{mmol} \mathrm{N} \mathrm{m}^{-3}$ & See Fig. 9 & Far field D \\
\hline $\mathrm{N}_{\text {in }}(\mathrm{t})$ & $\operatorname{mmol~} \mathrm{N} \mathrm{m}^{-3} \mathrm{~d}^{-1}$ & Variable & External TIN input \\
\hline $\mathrm{D}_{\text {in }}(\mathrm{t})$ & $\mathrm{mmol} \mathrm{N} \mathrm{m}^{-3} \mathrm{~d}^{-1}$ & 0 & External D input \\
\hline
\end{tabular}


values of $0.29 \mathrm{~d}^{-1}$ for Box 1 and $0.043 \mathrm{~d}^{-1}$ for Box 3 . We have set $I_{m}$ equal to 0 for Box 2 because of the relatively low clearance capacity of mussel spat. From the nitrogen budget, the excreted fraction $\beta_{\mathrm{m}}=26 / 230=$ 0.11 . Since the mussel portion of the budget is not fully balanced, we have treated the assimilated fraction, $\varepsilon_{\mathrm{m}}$, as a tuneable parameter and chosen its value so that the assimilated nitrogen matches the annual

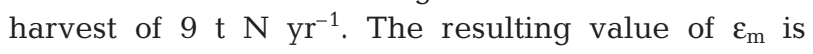
0.048. (Note that the assimilation efficiency is not the same as the absorption efficiency, but they are related by $\left.\mathrm{AE}=\beta_{\mathrm{m}}+\varepsilon_{\mathrm{m}}\right)$.

\section{Model applications}

The LTLM box model was applied to Tracadie Bay under 3 specific scenarios:

(1) Cumulative effect scenario representing the current state of Tracadie Bay with both the cultured mussel population (M) and land based TIN inputs at present day levels.

(2) Enrichment effect scenario without cultured mussels, but with land based $\mathrm{N}$ inputs at present levels. This scenario is used to assess the impact of the cultured mussels on the nitrogen dynamics of the ecosystem.

(3) Baseline scenario without cultured mussels and without land based inputs of $\mathrm{N}$. This scenario tests the effect of the mostly agricultural land based nitrogen source on nitrogen dynamics.

The model outputs are presented in Figs. 7 to 10 with each panel in these figures showing the model predictions for the above 3 scenarios. In addition, the plots for P, N and D (Figs. 7 to 10) show the observed concentrations (daily interpolations from the objective analysis) in each box and the offshore concentrations. Table 3 lists the amount of nitrogen in each reservoir and the annual fluxes between reservoirs as predicted by the model for each box.

First, we can compare the model predictions for the present day scenario (cumulative effects of mussels and nutrient enrichment) with the observations for $\mathrm{P}, \mathrm{N}$ and $\mathrm{D}$ in each of the model boxes. Both the $\mathrm{P}$ concentration ranges and the general seasonal patterns of the $\mathrm{P}$ distributions predicted by the model are consistent with observations. The model predicts spring and fall blooms in all 3 boxes, with summer values falling to 1-2 $\mu \mathrm{M} \mathrm{N}^{-1}$ (Fig. 7). However, the timing of the blooms predicted by the model are offset from the observations by up to 1 mo. For example, the predicted spring blooms in Boxes 1 and 3 are about 1 mo later than the observed blooms, while the predicted spring bloom in Box 2 is approximately 1 mo earlier. In addition, the fall blooms predicted by the model tend to be
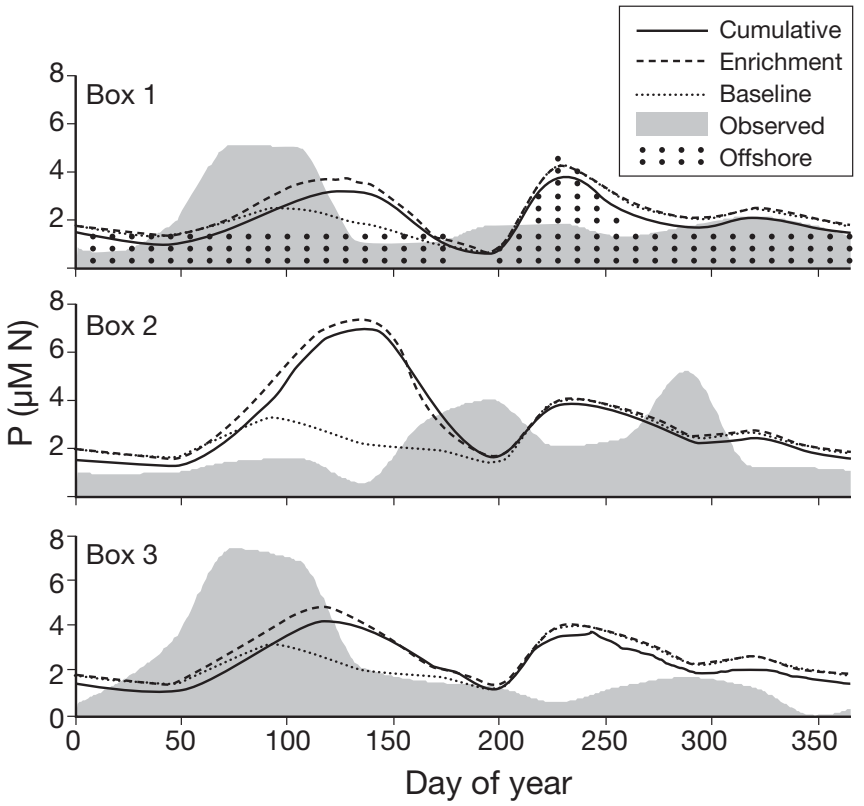

Fig. 7. Lower trophic level model predictions for phytoplankton concentrations (P), expressed as nitrogen equivalents. The model was run for 3 scenarios: (1) Cumulative = present day levels of mussels and freshwater nitrogen inputs; (2) Enrichment $=$ no mussels, but freshwater nutrient input to the Bay; and (3) Baseline = no mussels present and no freshwater nitrogen input. The top of the stippled area is the daily interpolated data for the offshore $\mathrm{P}$ concentration. The top of the shaded area is the daily interpolated data for the observations in each box

more intense than those observed. In the model, the highest spring $\mathrm{P}$ values occur in Box 2 (Winter Harbour) due to the high $\mathrm{N}$ levels and lack of mussel grazing pressure, but observations show the highest values are in Box 3 (head of Tracadie Bay).

The general spatial and temporal patterns in TIN (Fig. 8) conform with observations with highest values in spring falling to near zero concentrations in summer, and smaller increases early in fall that decline before the return of high values in the winter. Their spatial pattern is also consistent (highest in Box 2, then Box 3, then Box 1). However, the predicted magnitudes are much smaller than the observations in spring. As previously mentioned, the high TIN observations are based on a small number of samples collected through the ice and gaps in the sampling occur in the spring. We do not have data to indicate exactly when the high wintertime concentrations decrease and whether they contribute to spring productivity. The levels predicted by the model are consistent with a typical temperate seasonal cycle, modified by high inputs into Box 2 (especially during the spring freshet).

The modelled water column detrital pool (Fig. 9) shows a fairly constant mean level near $5 \mu \mathrm{M} N$ with episodic fluctuations due to resuspension events, 
Table 3. Nitrogen inventories (annual averages, $\mathrm{t} \mathrm{N}$ ) and fluxes $\left(\mathrm{t} \mathrm{N} \mathrm{yr}^{-1}\right)$ calculated from the lower trophic level model. Model scenarios are defined in the text. The 'exchange' terms for Boxes 1 to 3 are the net exchanges with other boxes or the offshore (positive terms are a net gain to the box). The 'Total' column is the exchange between Box 1 and the offshore, and represents the material lost or gained in all of Tracadie Bay by marine exchange. $\mathrm{P}=$ phytoplankton, $\mathrm{TIN}=$ inorganic nitrogen, $\mathrm{D}=$ detritus, $\mathrm{B}=$ benthos and $\mathrm{M}=$ mussels

\begin{tabular}{|c|c|c|c|c|c|c|c|c|c|c|c|c|}
\hline & \multicolumn{4}{|c|}{ Cumulate effects (Scenario 1) } & \multicolumn{4}{|c|}{ Enrichment effects (Scenario 2) } & \multicolumn{4}{|c|}{ Baseline (Scenario 3) } \\
\hline & Box 1 & Box 2 & Box 3 & Total & Box 1 & Box 2 & Box 3 & Total & Box 1 & Box 2 & Box 3 & Total \\
\hline $\mathrm{P}$ & 0.55 & 0.43 & 0.33 & 1.31 & 0.65 & 0.47 & 0.38 & 1.51 & 0.57 & 0.33 & 0.32 & 1.23 \\
\hline TIN & 1.45 & 1.24 & 0.71 & 3.40 & 1.24 & 1.15 & 0.59 & 2.98 & 0.97 & 0.49 & 0.49 & 1.96 \\
\hline $\mathrm{D}$ & 1.08 & 0.56 & 0.50 & 2.14 & 1.25 & 0.65 & 0.59 & 2.48 & 1.18 & 0.53 & 0.54 & 2.24 \\
\hline B & 8.02 & 0.11 & 0.30 & 8.43 & 0.36 & 0.13 & 0.13 & 0.62 & 0.34 & 0.10 & 0.12 & 0.56 \\
\hline $\mathrm{TIN} \rightarrow \mathrm{P}$ & 47 & 48 & 28 & 122 & 48 & 49 & 28 & 125 & 32 & 20 & 20 & 72 \\
\hline $\mathrm{P} \rightarrow \mathrm{D}$ & 18.4 & 25 & 13.0 & 56 & 26 & 29 & 17.3 & 72 & 19.4 & 12.8 & 12.2 & 44 \\
\hline $\mathrm{D} \rightarrow \mathrm{TIN}$ & 40 & 20 & 18.2 & 78 & 46 & 23 & 21 & 90 & 44 & 19.2 & 20 & 82 \\
\hline $\mathrm{B} \rightarrow \mathrm{TIN}$ & 92 & 1.9 & 4.4 & 99 & 4.2 & 2.3 & 2.0 & 8.4 & 3.9 & 1.78 & 1.79 & 7.5 \\
\hline $\mathrm{D} \rightarrow \mathrm{B}$ & 20 & 10.2 & 9.1 & 39 & 23 & 11.8 & 10.8 & 45 & 21 & 9.6 & 9.8 & 41 \\
\hline $\mathrm{B} \rightarrow \mathrm{D}$ & 13.6 & 2.0 & 3.7 & 19 & 4.4 & 2.3 & 2.1 & 8.8 & 4.2 & 1.88 & 1.90 & 8.0 \\
\hline $\mathrm{P} \rightarrow \mathrm{M}$ & 58 & 0 & 5.1 & 63 & 0 & 0 & 0 & 0 & 0 & 0 & 0 & 0 \\
\hline $\mathrm{D} \rightarrow \mathrm{M}$ & 114 & 0 & 8 & 122 & 0 & 0 & 0 & 0 & 0 & 0 & 0 & 0 \\
\hline $\mathrm{M} \rightarrow \mathrm{B}$ & 145 & 0 & 11 & 156 & 0 & 0 & 0 & 0 & 0 & 0 & 0 & 0 \\
\hline $\mathrm{M} \rightarrow \mathrm{TIN}$ & 19.0 & 0 & 1.4 & 20.4 & 0 & 0 & 0 & 0 & 0 & 0 & 0 & 0 \\
\hline$M$ harvest & 8.3 & 0 & 0.6 & 8.9 & 0 & 0 & 0 & 0 & 0 & 0 & 0 & 0 \\
\hline TIN river & 0 & 101 & 0 & 101 & 0 & 101 & 0 & 101 & 0 & 0 & 0 & 0 \\
\hline P exchange & 30.1 & -22.9 & -9.5 & -2.4 & -22 & -21 & -10.3 & -53 & -13.0 & -7.4 & -7.5 & -28 \\
\hline TIN exchange & -105 & -75.2 & 3.6 & -176 & -2.1 & -77 & 4.5 & -75 & -14.9 & -0.80 & -1.67 & -17.4 \\
\hline D exchange & 101 & -2.8 & 7.4 & 106 & 25 & -3.2 & 6.1 & 28 & 29 & 8.5 & 9.5 & 47 \\
\hline Burial & 74 & 1.53 & 3.5 & 79 & 3.3 & 1.81 & 1.60 & 6.7 & 3.1 & 1.43 & 1.44 & 6.0 \\
\hline
\end{tabular}
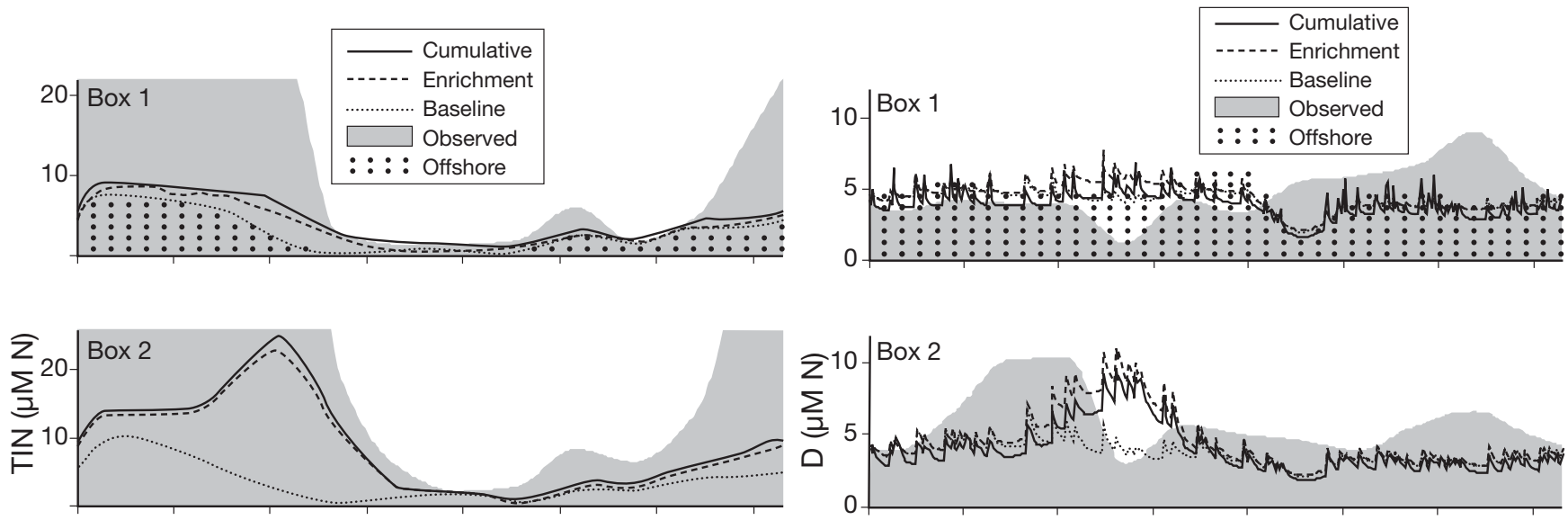

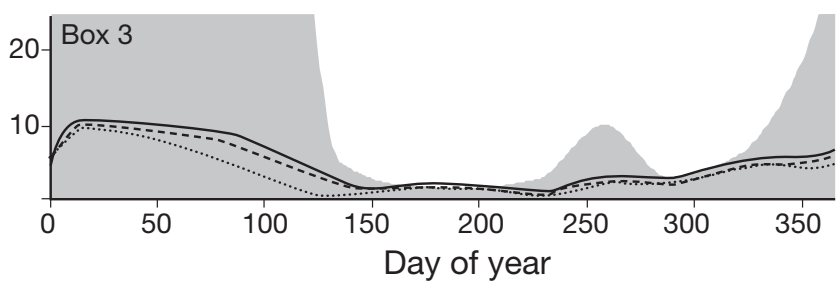

Fig. 8. Lower trophic level model predictions for nitrogen concentrations (TIN). The model was run for the 3 scenarios described in Fig. 7. The top of the stippled area is the daily interpolated data for the offshore TIN concentration. The top of the shaded area is the daily interpolated data for the observations in each box

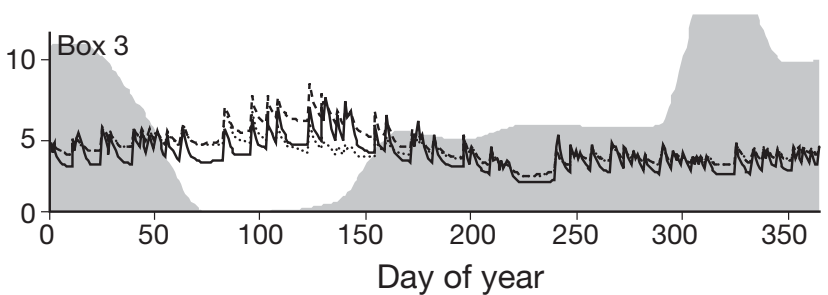

Fig. 9. Lower trophic level model predictions for detritus concentrations (D), expressed as nitrogen equivalents. The model was run for the 3 scenarios described in Fig. 7. The top of the stippled area is the daily interpolated data for the offshore D concentration. The top of the shaded area is the daily interpolated data for the observations in each box 
which is similar to both the observations in the individual boxes and to the levels offshore. The model also correctly predicts the shape and magnitude of the increase in D that occurs in Box 2 in the spring.

The benthos in the model may be thought of as an ecologically active pool (or layer) of nitrogen in which processes operate that result in resuspension, remineralization and burial of nitrogen. The model predicts highest values for the cumulative effects scenario, with Box 1 (greatest biomass of mussels) containing the vast majority of benthic nitrogen. The scenarios without mussels exhibited similar patterns and magnitude. Although the benthos is an ecologically significant reservoir, there are no measurements suitable for comparison with the model predictions shown in Fig. 10.

\section{DISCUSSION}

\section{Lower trophic level model scenarios}

A comparison of estimated annual average phytoplankton levels in the different model boxes for the cumulative (mussels) and enrichment (no mussels) scenarios (Table 3) show that mussel culture in Tracadie Bay affects all aspects of the nitrogen cycle to some degree. Mussel grazing reduces phytoplankton levels by 15, 9 and $13 \%$ in Box 1 (mouth of Tracadie Bay), Box 2 (Winter Harbour) and Box 3 (head of the Bay), respectively. Although the majority of mussels are located in Box 1, phytoplankton depletion occurs throughout the system owing to water exchange. The relatively large effect near the head of the Bay, despite

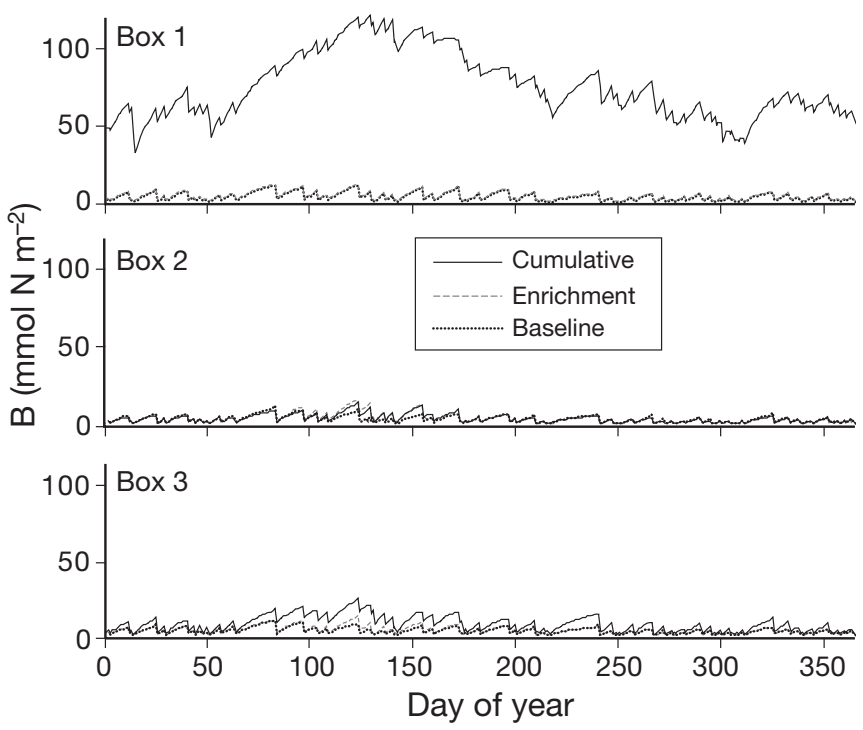

Fig. 10. Lower trophic level model predictions for nitrogen levels in the benthos (B). The model was run for the 3 scenarios described in Fig. 7 the presence of only $7 \%$ of the cultured mussel population, results from poor exchange with the offshore. Conversely, the impacts near the mouth are relatively small given that this area contains $92 \%$ of the cultured mussels, showing the importance of offshore exchange and the supply of phytoplankton from Winter Harbour in regulating phytoplankton levels. The conclusion that $\mathrm{P}$ is more reduced at the head of the Bay than in the mouth is consistent with observations of reduced mussel growth near the head of the Bay (Waite et al. 2005), as well as theoretical studies considering the competing role of $\mathrm{P}$ growth, $\mathrm{M}$ grazing, and the differential exchange processes (Dowd 2003).

Our predictions of reduced annual average P and D concentrations (13 and $14 \%$ reductions, respectively) in the scenario with mussels (Table 3 , Figs. $7 \& 9$ ) are consistent with results from other studies of Tracadie Bay. Grant et al. (in press) used a more complex ecosystem model to investigate seston depletion and reported considerably more severe effects of mussel culture on the overall $\mathrm{P}$ biomass than reported here. Those predictions were validated using results from detailed surveys of the bay-wide chl a distribution. The density of second year mussels in Grant et al. (in press) study (10 ind. $\mathrm{m}^{-3}$ ) represents total mussel stocking levels and is approximately double the value used in the current model application, which only considers the effects of the harvested stock. The falling trend detected in the weight of mussels harvested from Tracadie Bay during the 1990s, when annual stocking density was steadily increasing (Figs. 4.3 \& 4.4 in Cranford et al. 2006), implies a negative feedback on meat yields caused by bivalve induced food limitation. Over a 5 yr period, when mussel biomass in the Bay increased by more than $40 \%$, the average mass yield of mussel socks declined by $30 \%$. Together, these observations and model results indicate that the mussel production carrying capacity of Tracadie Bay has been exceeded.

The pathways by which the nitrogen reaches the phytoplankton are dramatically altered in the presence of the farmed mussels. Mussel deposition $(\mathrm{M} \rightarrow \mathrm{B})$ sends $156 \mathrm{t} \mathrm{N} \mathrm{yr}^{-1}$ to the benthos and the flux of nitrogen out of the sediments $(\mathrm{B} \rightarrow \mathrm{TIN}+\mathrm{B} \rightarrow \mathrm{D}$ ) is estimated to increase by $100 \mathrm{t} \mathrm{N} \mathrm{yr}^{-1}$, enough to supply more than $70 \%$ of phytoplankton nitrogen requirements. In the presence of mussels, $\mathrm{P} \rightarrow \mathrm{D}, \mathrm{D} \rightarrow \mathrm{B}$ and $\mathrm{D} \rightarrow$ TIN fluxes are smaller in all 3 boxes (Table 3), presumably because mussel grazing consumes P and D that would otherwise be part of these fluxes. Asmus \& Asmus (1991) raised the possibility that mussels promote phytoplankton production by remineralizing detrital material and by increasing rates of phytoplankton recycling during periods when $\mathrm{N}$ demand is high and ambient concentrations are low. 
The model estimates that the mussels ingest approximately twice as much detritus $\mathrm{N}$ than phytoplankton $\mathrm{N}$ (Fig. 6B, Table 3). The recycling of detrital $\mathrm{N}$ through mussel excretion and biodeposition pathways will promote phytoplankton growth during periods of $\mathrm{N}$ limitation and intensify bottom-up controls on the phytoplankton. However, similar fluxes of TIN $\rightarrow \mathrm{P}$ in model runs with and without mussels (Table 3) suggest no effect on annual phytoplankton production.

The impact of freshwater nitrogen inputs on annual average $\mathrm{P}$ levels in the different boxes can be seen from a comparison of the baseline (no mussels or inputs from land) and enrichment (no mussels) model runs (Table 3). As expected, freshwater inputs increased TIN and $P$ in all 3 boxes, with the greatest increases in Winter Harbour (Box 2) where the freshwater inputs occur. Removal of freshwater inputs resulted in $\mathrm{P}$ reductions in Winter Harbour by as much as $62 \%$ during the spring bloom (Fig. 7), and levels are reduced by as much as $50 \%$ in the remainder of the Bay. Although these large P reductions occur only in the spring (probably because the fall bloom is fuelled by nutrients from offshore), the changes are large enough to have a sizeable impact on total annual phytoplankton growth $\left(\mathrm{TIN} \rightarrow \mathrm{P}\right.$ ), which changes from $125 \mathrm{t} \mathrm{N} \mathrm{yr}^{-1}$ in the nutrient enriched scenario to $72 \mathrm{t} \mathrm{N} \mathrm{yr}^{-1}$ in the baseline scenario (Table 3 ). Therefore, a substantial fraction of the P present in Tracadie Bay is fuelled by land derived nitrogen. $\mathrm{P}$ levels outside Winter Harbour remained virtually the same as the current condition when both freshwater inputs and mussels are removed (compare the cumulative and baseline scenarios in Table 3). These comparisons indicate: (1) the effect of freshwater nitrogen on P levels is substantially greater than changes due to mussel grazing; and (2) cultured mussels in Tracadie Bay depend on terrestrial nitrogen inputs to produce much of their food. The latter agrees with ecosystem model predictions of the large effect of watershed nitrogen inputs on oyster production levels in the Thau Lagoon (Chapelle et al. 2000).

Comparisons of box model results for scenarios with and without mussels suggest that the presence of mussels increases retention of nitrogen from freshwater and offshore sources within the Bay. The mussels change the TIN export and $\mathrm{M} \rightarrow \mathrm{B}$ and $\mathrm{B} \rightarrow$ TIN fluxes by 101, 156 and $91 \mathrm{t} \mathrm{N} \mathrm{yr}^{-1}$ (increases of 2.3-, 14- and 12-fold, respectively). Smaller changes (2.5 to $15 \%$ ) also occur in the TIN $\rightarrow$ P and D $\rightarrow$ TIN fluxes when mussels are present. Inspection of import and export terms in Table 3 shows that the TIN export from Tracadie Bay is much larger in the presence of mussels

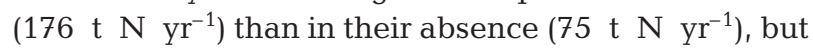
this change is more than offset by the corresponding reduction in $\mathrm{P}$ exports (51 $\mathrm{t} \mathrm{N} \mathrm{yr}^{-1}$ ) and the increase

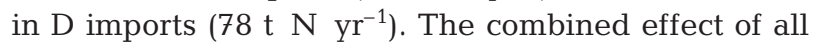

these changes is to produce slightly higher pelagic TIN levels and a much larger benthic nitrogen pool when mussels are present than when they are not (Table 3, Figs. 8 \& 10).

Dramatic changes in the relative role of the benthos in nitrogen cycling are apparent in the presence of mussels. Mussel biodeposition is 3.5-fold greater than the natural sedimentation $(\mathrm{D} \rightarrow \mathrm{B}$ ) when mussels are not present (Table 3) and nitrogen burial increases by $72 \mathrm{t} \mathrm{N} \mathrm{yr}^{-1}$, which is 11.8-fold more than if no mussels were present. Resuspension $(\mathrm{B} \rightarrow \mathrm{D})$ and remineralization $(\mathrm{B} \rightarrow \mathrm{TIN}$ ) increase by factors of 2.2 and 11.8, respectively. As expected, the bulk of the benthic flux in the model run with mussels occurs in Box 1, where the majority of mussel grow-out takes place. The high $B$ level in this region represents a potential for severe eutrophication effects on benthic communities. In contrast, the enrichment model run indicated that freshwater inputs have little impact on the nitrogen stored in the benthos (Table 3). However, the model predictions of the fate of nitrogen after it reaches the benthos are only as good as the model parameters controlling resuspension, remineralization and burial. Although there are no field data to validate these specific estimates, model formulations of the benthic component are based on robust equations of the important geochemical processes involved (Dowd 2005). Model predictions also parallel the results of a 2003 benthic geochemical survey of Tracadie Bay that showed that hypoxic and anoxic sediment conditions, indicative of extensive organic enrichment, were only found within mussel lease boundaries and that the majority ( $77 \%$ ) of sampling sites with free sulphide concentrations exceeding $1500 \mu \mathrm{M}$ (13 sites) were located within Box 1 (Cranford et al. 2006). Benthic macroinvertebrate communities throughout Tracadie Bay are described as having low diversity and a very low number of species (Miron et al. 2005).

Discrepancies between model predictions and observations (Figs. 7 to 10) could be due to model errors in the forcing and far field conditions. They might also be due to errors of representativeness in the point observations, e.g. a high productivity zone at the head of Winter Harbour may have been under sampled and so affected the seasonal cycles constructed by objective analysis. Also critical to this comparison is that the model scenarios are based on the influence of a mussel population equal to the amount harvested each year. Although estimates are not well constrained, the total mussel biomass in the Bay appears to be double the annual harvest even without consideration of wild mussel beds and oyster culture. The additional influences on nitrogen dynamics of large populations of other herbivores residing on mussel culture structures would also need to be modelled for a direct comparison 
between model output and observations to be valid. Finally, the modelling approach does consider potential aquaculture induced changes to phytoplankton community composition. Picophytoplankton cells, which are not captured by bivalves due to their small size, appear to contribute substantially to phytoplankton biomass in extensively cultured aquaculture embayments (Courties et al. 1994, Prins et al. 1998, Bec et al. 2005), including Tracadie Bay (Cranford et al. 2006, W. K. W. Li pers. comm.). The philosophy of the parsimonious LTLM model has been to offer simplicity, but not triviality, to quantitative descriptions of aquaculture systems by including only dominant processes (Dowd 2005). Although some realism is sacrificed for generality, the model applications are based on robust parameterizations and approximations, well defined boundary forcing, and data driven estimation of mixing coefficients. We feel that the resulting descriptions of observed parameters are therefore sufficient for the systematic testing of hypotheses concerning the effects of nutrient enrichment and mussel culture on nitrogen dynamics (Dowd 2005).

\section{Nitrogen budget}

Biomass and fluxes involving mussels in the budget and the model cannot be considered truly independent (calculated from similar underlying information) and will not be compared. However, it is possible to directly compare some budget calculations (Fig. 6A) with summed or averaged model estimates for the whole year for the combined mussel and nutrient enrichment (cumulative) scenario (Fig. 6B). Nitrogen inventories in the different reservoirs from the budget and the model are similar except for TIN, for which the model estimates are much lower (3.4 compared with $13 \mathrm{t} \mathrm{N}$ ). A little less $\mathrm{P}$ (2.4 versus $22 \mathrm{t} \mathrm{N} \mathrm{yr} \mathrm{r}^{-1}$ ) and a lot less TIN (176 versus $654 \mathrm{t} \mathrm{N} \mathrm{yr}^{-1}$ ) are exported in the model than in the budget, and a significant amount of $\mathrm{D}$ is imported in the model (106 $\left.\mathrm{t} \mathrm{N} \mathrm{yr}^{-1}\right)$, compared with $\mathrm{D}$ being in approximate balance in the budget (Fig. 6). The TIN levels and fluxes in the budget may have been biased by the high values obtained for the few available winter measurements. The budget has external nitrogen sources and sinks out of balance by 568 t $\mathrm{N} \mathrm{yr}^{-1}$. In contrast, sources and sinks are nearly in balance for all 3 model scenarios (Table 3 ).

The nitrogen budget presented here was based on relatively simple concepts applied to some basic characteristics of Tracadie Bay and measurements or estimates of nitrogen levels in a few reservoirs, freshwater inputs and relatively simple attempts to characterize the marine exchanges and fluxes associated with mussel feeding and excretion. Despite the simplifications, it was possible to derive the following noteworthy inferences on mussel/ecosystem interactions from the budget and associated calculations.

A comparison of the amount of nitrogen consumed by mussels with the inventories of nitrogen in their food ( $\mathrm{P}$ and $\mathrm{D}$ ) and in the mussels themselves shows that mussels exert a dominant role in the flow of nitrogen through the Tracadie Bay ecosystem (Fig. 6A). The mussels ingest approximately 50 -fold the average standing stock of the total nitrogen found in phytoplankton and detritus, which is equivalent to completely processing the available food supply once a week. The mussels turn over plankton nitrogen at an even higher rate ( $\sim \mathrm{d})$. Given that the mussel biomass in Tracadie Bay is roughly double the amount used for this budget, the phytoplankton production timescale would have to be on the order of a few days to support this level of aquaculture. Dowd (2003) estimated a production timescale of 2 to $5 \mathrm{~d}$ for phytoplankton in temperate coastal waters typical of Tracadie Bay during summer. Although primary production data for this Bay indicate remarkably high turnover times of 0.2 to $2.3 \mathrm{~d}$ (W. G. Harrison pers. comm.), the intensity of culture, in combination with the other herbivores (including zooplankton, wild mussel reefs, some oyster culture and the extensive fouling community on the mussel lines), is probably consuming available food at a faster rate than can be replenished by internal production. Seston transported into the Bay from offshore supplements the internal production. However, water residence time in Tracadie Bay (3.4 d; Grant at al. 2005 ) is longer than the 2 d estimated for mussel clearance of the tidal prism (Dowd 2003). A high potential for bay-wide food depletion is therefore indicated, which was also concluded from the model results.

The budget cannot test hypotheses on the effects of mussels or freshwater inputs on many important nitrogen reservoirs or internal fluxes, such as the biomass and productivity of phytoplankton, ambient TIN levels and benthic storage of nitrogen. Stated in other terms, the budget is not capable of testing the responses of Tracadie Bay to forcing due to mussels, freshwater inputs or to different scenarios in general. Models must be used to examine such internal processes and to test different scenarios. In addition, the model, unlike the budget, provided spatial information resolved to the geographic scale of the model boxes.

Although the budget has more limited application for testing hypotheses compared with the model, comparisons of nitrogen fluxes associated with the mussels with other fluxes in the budget (Fig. 6A) provide insights into potential pathways of aquaculture effects and have practical application. For example, a prevalent theory that can be addressed by the budget is that introduced bivalves modulate coastal eutrophication 
by clarifying the water and removing excess nitrogen in the harvest. The capacity for water clarification has already been confirmed as previously described. The ability of the bivalve harvest to remove anthropogenic nitrogen inputs from land use was examined by comparing freshwater inputs with the exported biomass. Mussel harvesting removes $9 \mathrm{t} \mathrm{N} \mathrm{y^{-1 }}$ from Tracadie Bay, which is equivalent to $9 \%$ of the total freshwater nitrogen input and $18 \%$ of nitrogen input estimates from agricultural run-off. Given that phytoplankton accounted for $40 \%$ of the total ingested nitrogen (Fig. $6 \mathrm{~A})$, only $3.6 \mathrm{t} \mathrm{N} \mathrm{yr}^{-1}$ of the mussel harvest could result directly from phytoplankton uptake of agricultural nitrogen, with an additional small amount removed via the $\mathrm{P} \rightarrow \mathrm{D} \rightarrow \mathrm{M}$ pathway (Fig. 6A). Therefore, only a small fraction of the agricultural nitrogen run-off $(<10 \%)$ appears to be removed by the intensive mussel culture operations in this Bay. Although the harvest does represent the loss of a considerable amount of anthropogenic nitrogen from the coastal zone, intensive bivalve aquaculture in Tracadie Bay does not appear to be an effective tool for coastal managers to control nutrient emissions from land-use.

Mussel excretion and biodeposition represents significant fluxes in the nitrogen budget (Fig. 6A) and must be considered along with grazing in any assessment of the overall effects of aquaculture, including potential interactions with the effects of nitrogen enrichment. Annual excretion by the harvested biomass returns an amount of nitrogen to the water column equivalent to approximately $50 \%$ of the agricultural run-off, while biodeposition was estimated to be 3 times greater than agricultural inputs (Fig. 6A). Both fluxes from mussels were similar in magnitude to estimates from the lower trophic level model (Fig. 6) and similar conclusions can be drawn about their potential ecological significance. Excretion by suspended mussels recycles nitrogen directly into nutrient depleted waters. TIN levels in Tracadie Bay in late summer and fall, although low, are dominated by ammonia, and silicate is generally the limiting nutrient for diatom growth and carrying capacity (Bates \& Strain 2007). A combination of rapid uptake of TIN by microalgae and the net export of nitrogen to the offshore probably maintains ambient TIN at depleted levels during much of the year (Fig. 3).

Our estimate of the flux of nitrogen to the sediments due to the harvested mussel biomass (154 $\mathrm{t} \mathrm{N} \mathrm{yr}^{-1}$ ) is equivalent to $105 \mathrm{mg} \mathrm{N} \mathrm{m}^{-2} \mathrm{~d}^{-1}$ if the deposition was uniformly distributed over the $\sim 4 \mathrm{~km}^{2}$ area of mussel grow-out leases, and is approximately $200 \mathrm{mg} \mathrm{N} \mathrm{m}^{-2}$ $\mathrm{d}^{-1}$ when scaled up to the total mussel biomass in the Bay (approximately twice the harvested biomass). Grant et al. (2005) measured sedimentation rates in Tracadie Bay and observed that rates under mussel lines were approximately double those at reference sites. An average biodeposition flux of $405 \mathrm{mg} \mathrm{N} \mathrm{m}^{-2}$ $\mathrm{d}^{-1}$ was estimated from Grant et al. (2005) by subtracting natural sedimentation at the reference sites from total vertical flux at the mussel sites and assuming a $\mathrm{N}$ content of $1.5 \%$ of dry faeces weight (Kautsky \& Evans 1987). This flux is higher than in our budget, as would be expected considering that the sediment traps were placed close to the mussel lines, while our estimate also includes areas between lines spaced $\sim 5$ m apart.

\section{Reliability of budget estimates}

A discussion of the nitrogen budget must consider the confidence with which the budget estimates are determined. Three independent means (two based on data and one based on nutrient export coefficients) were available for estimating the freshwater inputs of TIN and they agreed to within $\pm 26 \%$, which makes the freshwater input well known by the standards of these kinds of calculations. The agricultural component of the freshwater input is based on applying published nutrient export coefficients for nitrogen loading and comprehensive databases on land use and river flow. Although nutrient loading will vary with the type of agriculture (Frink 1991), applying the known range of coefficients does not significantly affect our conclusions.

The nitrogen exchanges due to the mussels are expected to be reasonably constrained by the basic physiology of the mussels. Although these fluxes are based on laboratory measurements of individual mussels that were scaled up to an entire population in a real environment, this is a common practice and the allometric relationships employed for clearance rate provide results comparable with field measurements on mussel cohorts (Cranford \& Hill 1999). One test of the mussel component of the budget is to compare the total inputs and outputs of nitrogen with the mussels. The mussels consumed $230 \mathrm{t} \mathrm{N} \mathrm{yr}^{-1}$, and $189 \mathrm{t} \mathrm{N}$ $\mathrm{yr}^{-1}$ of that consumption is accounted for in mussel production, urine and faeces (Fig. 6A). Overall, nitrogen processed through mussels is balanced to within $\sim 18 \%$, which is within the bounds expected for this kind of a budget.

The offshore exchange estimates in the nitrogen budget must be considered first order. Tidal prism calculations usually overestimate tidal transport because the underlying assumptions of complete mixing within the Bay and infinite dilution outside the Bay are approximations only. These calculations only consider exchanges due to the tide and do not include exchanges due to other processes such as wind and storm events. Applying the exchange coefficient for 
Tracadie Bay and the offshore, derived from a heat budget calculation $\left(\mathrm{K}_{\infty}=1.3 \mathrm{~d}^{-1}\right.$; Dowd 2005), resulted in net export estimates for P, TIN and D of 28, 850 and $1.6 \mathrm{t} \mathrm{N} \mathrm{yr}^{-1}$, respectively. These values are somewhat higher than those predicted from the tidal prism (Fig. 6A), but they are within the same range. The budget estimates a large net export of all nitrogen forms from Tracadie Bay of $568 \mathrm{t} \mathrm{N} \mathrm{yr}^{-1}(=\Sigma$ outputs $-\Sigma$ inputs). A large export value was predicted independent of whether the tidal prism or heat budget exchange calculation was used, and is most likely due to the high winter TIN concentrations that heavily influenced the TIN inventory. Despite a potential for bias, the TIN inventory was only $13 \mathrm{t} \mathrm{N}$ and the calculations of the nitrogen held in $\mathrm{P}$ and $\mathrm{D}$ are not subject to this uncertainty. Given these evaluations of confidence in the different budget estimates, conclusions derived from the freshwater inputs and the mussel processing of nitrogen are based on a more solid foundation than those derived from the marine exchanges of nitrogen. The focus of this discussion was therefore on the former two aspects of Tracadie Bay nitrogen dynamics.

\section{CONCLUSIONS}

The following general conclusions about the cumulative influence of nutrient enrichment and mussel aquaculture in Tracadie Bay were derived from the nitrogen budget and lower trophic level model:

(1) Mussels play a dominant role in nitrogen cycling in Tracadie Bay and influence all aspects of the nitrogen cycle.

(2) A substantial fraction of the phytoplankton production in this inlet is fuelled by land derived nitrogen.

(3) The mussels depend on nitrogen in agricultural discharges to produce phytoplankton biomass, as well as on phytoplankton and detritus (a major part of the food supply) imported from offshore. That is, the internal production of the Bay is insufficient to support the harvested biomass of mussels.

(4) Mussels are consuming available food at a faster rate than can be replenished by internal and external processes. The budget and box model calculations indicate that the productive capacity of Tracadie Bay for mussel aquaculture has been reached.

(5) Food may be less available to mussels at the head of the Bay than at the mouth, despite the lower density of grow-out sites in the former location.

(6) The amount of nitrogen removed in the mussel harvest is small $(<10 \%)$ compared with the nitrogen in agricultural inputs.

(7) Mussels direct $\sim 20$ times more nitrogen to the water column and sediments in their urine and biode- posits than is removed in the harvest and these processes increase coastal nitrogen retention and dramatically alter pathways by which nitrogen reaches the phytoplankton.

(8) Mussel biodeposition results in a very large flux of nitrogen to the benthos, with potentially serious eutrophication effects.

At the modeled level of mussel production, the pelagic ecosystem components are much less sensitive to the effects of mussels than the benthic components due to the ability of external exchanges and feedbacks within the pelagic system to mitigate much of the effect. However, the rapid depletion of external food supplies by mussels places increased pressure on accelerated benthic remineralization processes and benthic/pelagic fluxes to maintain the phytoplankton reservoir. Bivalve aquaculture utilizes nutrients already present in the system, including those originating from land use and, therefore, does not cause coastal nutrient enrichment. However, it does determine where eutrophication from excess nutrient runoff is expressed by accelerating organic matter transport to the seabed and thereby facilitating the retention of nutrients in the coastal zone. Excessive benthic organic loading from biodeposition can lead to sediment anoxia. Anoxic conditions inhibit nitrification and denitrification (Newell 2004) and dissimilatory nitrate reduction to ammonium (Nizzoli et al. 2006) and would contribute to a greater impact on $\mathrm{N}$ dynamics than estimated by the present model.

The nitrogen budget is a relatively simple representation of the marine exchanges and fluxes associated with mussel aquaculture and terrestrial inputs in Tracadie Bay compared with the dynamic ecosystem model. However, results from both approaches are consistent and the lower trophic level model results do not contradict any important conclusions from the budget. However, the finer resolution of the box model and the ability to test different scenarios and predictions leads to additional conclusions. The number of fundamental ecosystem processes influenced by mussels and the complexity of their interactions makes it difficult to predict the impacts of mussels on many ecosystem properties without resorting to a model. The detailed insight provided by a dynamic model on ecosystem function can provide important information on issues like suitable distributions of leases in an inlet that are beyond the scope of a budget.

Acknowledgements. We gratefully recognize the contributions of many individuals involved in the Tracadie Bay ecosystem study. S. L. Armsworthy and V. Burdett-Coutts provided field and laboratory technical support for water sample collection and analyzed the SPM and chlorophyll samples. D. Keen conducted the weekly sampling program in Winter River. C. Anstey analyzed the nutrient samples and G. Bugden pro- 
vided some hydrographic data and guidance on tidal flushing. We acknowledge the 3 anonymous reviewers for their comments on the manuscript. This work was funded by Fisheries and Oceans Canada through its ESSRF program.

\section{LITERATURE CITED}

Asmus H, Asmus RM (1991) Mussel beds: limiting or promoting phytoplankton. J Exp Mar Biol Ecol 148:215-232

Bates SS, Strain PM (2007) Nutrients and phytoplankton in Prince Edward Island inlets: 2001-2003. Can Tech Rep Fish Aquat Sci (in press)

Bec B, Husseini-Ratrema J, Collos Y, Souchu P, Vaquer A (2005) Phytoplankton seasonal dynamics in a Mediterranean coastal lagoon: emphasis on the picoeukaryotic community. J Plankton Res 27:881-894

Bretherton FP, Davis RE, Fandry CB (1976) A technique for objective analysis and design of oceanographic experiments applied to MODE-73. Deep-Sea Res 23:559-582

Chapelle A, Ménesguen A, Deslous-Paoli JM, Souchu P, Mazouni N, Vaquer A, Millet B (2000) Modelling nitrogen, primary production and oxygen in a Mediterranean lagoon. Impact of oysters farming and inputs from the watershed. Ecol Model 127:161-181

Cloern JE (2001) Our evolving conceptual model of the coastal eutrophication problem. Mar Ecol Prog Ser 210: 223-253

Courties C, Vaquer A, Lautier J, Troussellier M, ChrétiennotDinet MJ, Neveux J, Machado C, Claustre H (1994) Smallest eukaryotic organism. Nature 370:255

Cranford PJ, Hill PS (1999) Seasonal variation in food utilization by the suspension-feeding bivalve molluscs Mytilus edulis and Placopecten magellanicus. Mar Ecol Prog Ser 190:223-239

Cranford PJ, Dowd M, Grant J, Hargrave B, McGladdery S (2003) Ecosystem level effects of marine bivalve aquaculture. In: Fisheries and Oceans Canada. A scientific review of the potential environmental effects of aquaculture in aquatic ecosystems, Vol 1. Can Tech Rep Fish Aquat Sci 2450:51-95

Cranford PJ, Anderson R, Archambault P, Balch T and 12 others (2006) Indicators and thresholds for use in assessing shellfish aquaculture impacts on fish habitat. Can Sci Advis Sec Res Doc 2006/034, Can Dept Fish Oceans, Ottawa

Dame RF (1996) Ecology of marine bivalves: an ecosystem approach. CRC Press, Boca Raton, FL

Dame RF, Prins TC (1998) Bivalve carrying capacity in coastal ecosystems. Aquat Ecol 31:409-421

DFO (Department of Fisheries and Oceans) (2005) 2004 Canadian aquaculture production statistics, Dept Fish Oceans. Available at www.dfo-mpo.gc.ca/communic/ statistics/aqua/index_e.htm

Doering PH, Oviatt CA (1986) Application of filtration rate models to field populations of bivalves: an assessment using experimental mesocosms. Mar Ecol Prog Ser 31: 265-275

Doering PH, Oviatt CA, Beatty LL, Banzon VF, Rice R, Kelly SP, Sullivan BK, Frithsen JB (1989) Structure and function in a model coastal ecosystem: silicon, the benthos and eutrophication. Mar Ecol Prog Ser 52:287-299

Dowd M (2003) Seston dynamics in a tidal inlet with shellfish aquaculture: a model study using tracer equations. Estuar Coast Shelf Sci 57:523-537

Dowd M (2005) A biophysical model for assessing environmental effects of marine bivalve aquaculture. Ecol Model 183: 323-346
Dowd M, Page F, Losier R, McCurdy P, Budgen G (2001) Physical oceanography of Tracadie Bay, PEI: analysis of sea level, current, wind and drifter data. Can Tech Rep Fish Aquat Sci 2347

Dowd M, Page F, Losier R (2002) Time series analysis of temperature, salinity, chlorophyll and oxygen data from Tracadie Bay, PEI. Can Tech Rep Fish Aquat Sci 2441

Figueiras FG, Labarta U, Fernández Reiriz MJ (2002) Coastal upwelling, primary production and mussel growth in the Rías Baixas of Galicia. Hydrobiologia 484:121-131

Frink CR (1991) Estimating nutrient exports to estuaries. J Environ Qual 20:717-724

Grant J, Cranford PJ, Hargrave B, Carreau M, Schofield B, Armsworthy S, Burdett-Coutts V, Ibarra D (2005) A model of aquaculture biodeposition for multiple estuaries and field validation at blue mussel (Mytilus edulis) culture sites in eastern Canada. Can J Fish Aquat Sci 62: 1271-1285

Grant J, Bacher C, Cranford PJ, Guyondet T, Carreau M (in press) A spatially explicit ecosystem model of seston depletion in dense mussel culture. J Mar Syst

Hawkins AJS, Bayne BL (1985) Seasonal variation in the relative utilization of carbon and nitrogen by the mussel Mytilus edulis: budgets, conversion efficiencies and maintenance requirements. Mar Ecol Prog Ser 25:181-188

Kautsky N, Evans S (1987) Role of biodeposition by Mytilus edulis in the circulation of matter and nutrients in a Baltic coastal ecosystem. Mar Ecol Prog Ser 38:201-212

Kérouel R, Aminot A (1997) Fluorometric determination of ammonia in sea and estuarine waters by direct segmented flow analysis. Mar Chem 57:265-275

Lindahl O, Hart R, Hernroth B, Kollberg S and 6 others (2005) Improving marine water quality by mussel farming: a profitable solution for Swedish society. Ambio 34:131-138

Mazouni N (2004) Influence of suspended oyster cultures on nitrogen regeneration in a coastal lagoon (Thau, France). Mar Ecol Prog Ser 276:103-113

Miron G, Landry T, Archambault P, Frenette B (2005) Effects of mussel culture husbandry practices on various benthic characteristics. Aquaculture 250:138-154

Newell RIE (2004) Ecosystem influences of natural and cultivated populations of suspension-feeding bivalve molluscs: a review. J Shellfish Res 23:51-61

Nizzoli D, Welsh DT, Fano EA, Viaroli P (2006) Impact of clam and mussel farming on benthic metabolism and nitrogen cycling, with emphasis on nitrate reduction pathways. Mar Ecol Prog Ser 315:151-165

Prins TC, Escaravage V, Smaal AC, Peters JCH (1995) Nutrient cycling and phytoplankton dynamics in relation to mussel grazing in a mesocosm experiment. Ophelia 41:289-315

Prins TC, Smaal AC, Dame RF (1998) A review of the feedbacks between bivalve grazing and ecosystems processes. Aquat Ecol 31:349-359

Raymond BG, Crane CS, Cairns DK (2002) Nutrient and chlorophyll trends in Prince Edward Island estuaries. In: Cairns DK (ed) Effects of land use practices on fish, shellfish, and their habitats on Prince Edward Island. Can Tech Rep Fish Aquat Sci 2408:142-153

Rice MA (2000) Filter feeding to control eutrophication. Environ Cape Cod 3:1-8

Rice MA (2001) Environmental impacts of shellfish aquaculture: filter feeding to control eutrophication. In: Tlusty MF, Bengston DA, Halvorson HO, Oktay SD, Pearce JB, Rheault Jr RB (eds) Marine aquaculture and the environment: a meeting of stakeholders in the northeast. Cape Cod Press, Falmouth, MA, p 76-86

Richard M, Archambault P, Thouzeau G, Desrosiers G (2006) Influence of suspended mussel lines on the bio- 
geochemical fluxes in adjacent water in the Îles-de-laMadeleine (Quebec, Canada). Can J Fish Aquat Sci 63: 1198-1213

Smaal AC, Prins TC (1993) The uptake of organic matter and the release of inorganic nutrients by suspension feeding bivalve beds. In: Dame RF (ed) Bivalve filter feeders in estuarine and coastal ecosystem processes. Springer-Verlag, Heidelberg, p 273-298

Smaal AC, Vonck APMA (1997) Seasonal variation in C, N and $\mathrm{P}$ budgets and tissue composition of the mussel Mytilus edulis. Mar Ecol Prog Ser 153:167-179

Editorial responsibility: Otto Kinne (Editor-in-Chief), Oldendorf/Luhe, Germany
Smaal AC, Vonck APMA, Bakker M (1997) Seasonal variation in physiological energetics of Mytilus edulis and Cerastoderma edule of different size classes. J Mar Biol Assoc UK 77:817-83

Strain PM, Clement PM (1996) Nutrient and dissolved oxygen concentrations in the Letang Inlet, New Brunswick, in the summer of 1994. Can Data Rep Fish Aquat Sci 1004

Waite L, Grant J, Davidson J (2005) Bay-scale spatial growth variation of mussels Mytilus edulis in suspended culture, Prince Edward Island, Canada. Mar Ecol Prog Ser 297: 157-167

Submitted: September 25, 2006; Accepted: March 20, 2007 Proofs received from author(s): September 5, 2007 